\title{
Comparative anatomy and development of pectoral and pelvic girdles in hylid anurans
}

\author{
Mónica C. Soliz ${ }^{1}$ | María Laura Ponssa² 이 | Virginia Abdala 3,4
}

\author{
${ }^{1}$ CONICET - Facultad de Ciencias Naturales, \\ Universidad Nacional de Salta, Salta, \\ Argentina \\ ${ }^{2}$ Unidad Ejecutora Lillo, UEL, \\ FML-CONICET, Tucumán, Argentina \\ ${ }^{3}$ Instituto de Biodiversidad Neotropical, \\ UNT-CONICET, Yerba Buena, Tucumán, \\ Argentina \\ ${ }^{4}$ Cátedra de Biología General, Facultad de \\ Ciencias Naturales e IML, UNT, Tucumán, \\ Argentina
}

\section{Correspondence}

Virginia Abdala, Instituto de Biodiversidad Neotropical, UNT-CONICET, Horco Molle s/n, Yerba Buena, Tucumán 4107, Argentina.

Email: virginia@webmail.unt.edu.ar

\section{Funding information}

CONICET, Grant/Award Number: PIP 389; ANPCyT, Grant/Award Number: PICT 2016-2772; ANPCyT, Grant/Award Number: PICT 2015-1618

\begin{abstract}
The development of the tetrapod pectoral and pelvic girdles is intimately linked to the proximal segments of the fore- and hindlimbs. Most studies on girdles are osteological and provide little information about soft elements such as muscles and tendons. Moreover, there are few comparative developmental studies. Comparative data gleaned from cleared-and-stained whole mounts and serial histological sections of 10 species of hylid frogs are presented here. Adult skeletal morphology, along with bones, muscles, and connective tissue of both girdles and their association with the proximal portions of the anuran fore- and hindlimbs are described. The data suggest that any similarity could be attributable to the constraints of their ball-and-socket joints, including incorporation of the girdle and stylopodium into a single developmental module. An ancestral state reconstruction of key structures and developmental episodes reveals that several development events occur at similar stages in different species, thereby preventing heterochronic changes. The medial contact of the halves of the pectoral girdle coincides with the emergence of the forelimbs from the branchial chamber and with the total differentiation of the linkage between the axial skeleton and the girdles. The data suggest that morphogenic activity in the anterior dorsal body region is greater than in the posterior one, reflecting the evolutionary sequence of the development of the two girdles in ancient tetrapods. The data also document the profound differences in the anatomy and development of the pectoral and pelvic girdles, supporting the proposal that the pectoral and pelvic girdles are not serially homologous, as was long presumed.
\end{abstract}

\section{KEYWORDS}

anuran morphology, histology, Hylidae, muscles, skeleton, tendons

\section{1 | INTRODUCTION}

The exploitation of the terrestrial environment is associated with the appearance of limbs that are connected to the axial skeleton by means of the girdles. However, each of these structures seems to have arisen at different times in the course of evolution. Thus, fossil evidence suggests a time gap of approximately 20 Mya in the acquisition of girdles, with the pectoral girdle predating the pelvic one (Sears, Capellini, \& Diogo, 2015; Zhu, Yu, Choo, Wang, \& Jia, 2012). The basal, finned tetrapods (i.e., Eusthenopteron) have robust hindlimbs and a pelvic girdle that is smaller than the pectoral girdle (Sears et al., 2015; Shubin, Daeschler, \& Jenkins, 2014). Likewise, comparison of the fore- and hindlimb skeletons of Ichthyostega stensioei the iconic earliest tetrapod, shows that the forelimbs are configured in a tetrapod-like posture, whereas the hindlimbs are paddle-like and reminiscent of a fish-like posture (Coates \& Ruta, 2007). Synchronous changes at the forelimb/ girdles and hindlimb/girdles are rare; thus, the condition of the pectoral girdle is not correlated with that of the pelvis (Coates \& Ruta, 2007). Similarly, functional differences between pectoral and pelvic structures seem to be rooted deep in the tetrapod phylogeny, with a shift in locomotory dominance from the forelimb to the hindlimb, as seen in Acanthostega and Ichthyostega (Boisvert, 2005).

Because both girdles are equally important to move the limbs efficiently, there have been a considerable number of studies of the pectoral girdle (Baleeva, 2001, 2009; Borkhvardt \& Baleeva, 2002; McGonell, 2001; Robovská-Havelková, 2010; Shearman, 2005, 2008) and the pelvic girdle (Manzano, Abdala, Ponssa, \& Soliz, 2013; Manzano \& Barg, 2005; Pomikal, Blumer, \& Streicher, 2011; Ročková \& 
Roček, 2005; Simons, 2008). However, the lack of studies that compare the anatomy and development of both girdles is striking (see Carroll \& Holmes, 2007; Sears et al., 2015). Moreover, the many studies of tetrapod girdles limited to the morphology and development of bony elements, emphasize the need to examine the soft elements, such as muscles and tendons. The limitations are understandable though. Fossils rarely provide any information about soft structures; therefore, comparisons among them and between them and recent taxa must be based on bony structures. Additionally, studies on soft tissues should include histological evidence, which is tedious, time-consuming, and expensive to acquire.

As an iconic example of tetrapods that transition between terrestrial and aquatic environments, anurans are an appropriate group in which to compare the characteristics of the pectoral and pelvic girdles. Developmentally, this transition requires a dramatic reorganization of almost all larval morphological structures to adjust from swimming to jumping, walking, hopping, and so on. Each mode of locomotion necessitates a distinct repertoire of different movements by the pectoral and pelvic appendicular apparatuses.

We present comparative data recorded from cleared-and-stained whole mounts and serial histological sections of 10 species of hylid frogs. We studied adult skeletal morphology and the development of bones, muscles, and connective tissue of the pectoral and pelvic girdles, as well as the association of the girdles with the proximal parts of the fore- and hindlimbs. Based on a matrix primarily composed of developmental data, we optimized the characters on the most recent published phylogeny for hylids (Duellman, Marion, \& Hedges, 2016) to identify evolutionary trends of girdle structure in the family. Comparative studies of girdles are particularly relevant to elucidate serial homologies in their structure (Diogo \& Molnar, 2014; Diogo \& Tanaka, 2014; Diogo \& Ziermann, 2014, 2015; Diogo, Linde-Medina, Abdala, \& Ashley-Ross, 2013; Sears et al., 2015), especially given that the ontogeny of the proximal limb segments is closely associated with the development of the girdles (Dos Santos, Fratani, Ponssa, \& Abdala, 2017; Manzano et al., 2013; Pomikal \& Streicher, 2010; Pomikal et al., 2011). Additionally, our understanding of the development of anuran girdles is limited in contrast to our understanding of limb development. Our work could contribute to fill in the gap in this interesting morphological and evolutionary issue.

\section{2 | MATERIALS AND METHODS}

\subsection{Cartilage and bone staining}

We examined 224 specimens of 10 species of hylid anurans (Table 1). The vertebral skeleton and, pectoral and pelvic girdles were examined in larval series. The specimens belong to Stages 32-46 of Gosner (1960). We analyzed Boana riojana Koslowsky, 1895, Lysapsus limellum Cope 1862, Pithecopus azureus Cope, 1862, Phyllomedusa boliviana Boulenger, 1902, Phyllomedusa sauvagii Boulenger, 1882, Pseudis platensis Gallardo 1961, Scinax acuminatus Cope 1862, Trachycephalus typhonius Linnaeus 1758, Scinax fuscovarius Lutz, 1925, and Scinax sp. Two adult $L$. limellum also were studied. All specimens were doublestained with Alcian Blue and Alizarin Red, and then cleared (Wassersug,
1976). Specimens were examined and illustrated with the aid of a Zeiss Discovery V8 stereoscope with a Nikon Coolpix P6000, 5-megapixel digital camera. Terminology of the anatomical structures and character definition follows those of Trueb (1973), Emerson (1979), Duellman and Trueb (1986), Ročková and Roček (2005), Abdala and Diogo (2010), Ponssa, Goldberg, and Abdala (2010), Přikryl, Aerts, Havelková, Herrel, and Rocek (2009), and Diogo and Molnar (2014) (Tables 2 and 3). To describe the ontogeny of several muscles and to identify their origin and insertion areas accurately, specific regions in the girdles were defined (Figure 1). The background of the figures was cleaned and the figures edited with Adobe Photoshop CS6 version 13.0x32.

\section{2 | Histology}

Twelve specimens between Stages 32 and 46 and two adults hylids were examined histologically: Lysapsus limellum FML 28180 (Stages: 37 40, 44, 46), Boana riojana FML 28174 (Stages: 37, 41, 44, 46) and Phyllomedusa sauvagii FML 28131 (Stages: 36, 38), and FML 28129 (Stages: $44,46)$. The specimens were dehydrated through a graded ethanol series, cleared in xylene and embedded in Paraplast. Embedded specimens were sectioned in serial and semi-serial sections of 5-10 $\mu \mathrm{m}$. Sections were deparaffinized, hydrated, and stained with Hematoxylin-Eosin $(\mathrm{H}-\mathrm{E})$. All sections were then dehydrated, bathed in xylene, and sealed with Canada Balsam under a cover slip. The terminology of the girdle tissues follows that of Baleeva (2001), Shearman (2008), and Manzano et al. (2013). This study was performed with specimens from herpetological collections; thus, collection permits and documentation of ethical treatments do not apply.

Twenty-six characters obtained from whole-mount stained specimens and histological samples were recorded in a matrix (Supporting Information S1) based on our observations in order to perform an ancestral state reconstruction. We mapped the characters using parsimony on the phylogenetic cladogram of Hylidae proposed by Duellman, Marion, \& Hedges (2016), reduced to the species surveyed. Only unambiguous changes were considered. Optimizations were performed with TNT software (Goloboff, Farris, \& Nixon, 2008) and the resulting cladogram was edited with Winclada1.00.08 software (Nixon, 2002). We adopt the nomenclatural arrangement proposed by Dubois (2017), and use Boana as the appropriate generic name for Hypsiboas.

\section{3 | Character list}

The character states of developmental characters were coded following the conventionally recognized Gosner (1960) stages: Larval I: Stages 26-30; Larval II: Stages 31-33; Larval III: Stages 34-37; Larval IV: Stages 38-41; Early metamorphic: Stages 42-44; and Late metamorphic: Stages 45 and 46

1. Differentiation of the cartilaginous elements of pectoral girdle: (0) Larval III; (1) Larval IV.

2. Differentiation of the cartilaginous elements of pelvic girdle: (0) Larval II; (1) Larval III; (2) Larval IV. 
TABLE 1 Material examined for osteological features

\begin{tabular}{|c|c|c|c|}
\hline Cleared and stained species & Stages & $N$ & Specimen number \\
\hline \multirow[t]{7}{*}{ Boana riojana } & Adult & 4 & FML 28137, MCN807, MCN799 \\
\hline & $26-30$ & 4 & FML 28175 \\
\hline & $31-33$ & 4 & FML 28173 \\
\hline & $34-37$ & 8 & FML 28174 \\
\hline & $38-41$ & 8 & FML 28174 \\
\hline & $42-44$ & 4 & FML 28174 \\
\hline & 45 and 46 & 2 & FML 28174 \\
\hline \multirow[t]{8}{*}{ Lysapsus limellum } & Adult & 2 & MLP DB2054, MLP DB2049 \\
\hline & $26-30$ & 4 & FML28180 \\
\hline & 29 & 1 & FML28180 \\
\hline & $31-33$ & 2 & FML28180 \\
\hline & $34-37$ & 6 & FML28180 \\
\hline & $38-41$ & 3 & FML28180 \\
\hline & $42-44$ & 4 & FML28180 \\
\hline & 45 and 46 & 5 & FML28180 \\
\hline \multirow[t]{6}{*}{ Pithecopus azureus } & Adult & 3 & FML 28151, FML 28150, FML04286 \\
\hline & 31 & 1 & FML 28126 \\
\hline & $36-37$ & 3 & FML 28127, FML 28128, FML 28126 \\
\hline & $38-40$ & 3 & FML 28128 \\
\hline & $42-44$ & 6 & FML 28126, FML 28128 \\
\hline & 45 and 46 & 3 & FML 28128 \\
\hline \multirow[t]{4}{*}{ Phyllomedusa boliviana } & Adult & 4 & FML02706, FML01305-7, FML1345-22, MCN326 \\
\hline & 36 & 1 & MCN992 \\
\hline & $38-41$ & 2 & MCN992, MCN991 \\
\hline & $42-44$ & 4 & MCN991, MCN991, LGE 11528, LGE 11528 \\
\hline \multirow[t]{6}{*}{ Phyllomedusa sauvagii } & Adult & 3 & MCN258, FML 28148, FML3823 \\
\hline & 33 & 2 & FML 28131 \\
\hline & $34-37$ & 7 & FML 28131 \\
\hline & $38-41$ & 6 & MCN 057 \\
\hline & $42-44$ & 9 & FML 28665, FML 28130 \\
\hline & 45 and 46 & 6 & FML 28129 \\
\hline \multirow[t]{9}{*}{ Pseudis platensis } & Adult & 4 & FML 28152, FML 28153, FML 28154 \\
\hline & $<26$ & 3 & MCN 613 \\
\hline & 28 & 2 & MCN 597 \\
\hline & $26-30$ & 1 & FML 20179 \\
\hline & $31-34$ & 1 & MCN613 \\
\hline & $35-37$ & 1 & FML 28179 \\
\hline & $37 / 38$ & 1 & MCN 613 \\
\hline & $38-41$ & 1 & FML 20178 \\
\hline & 43 & 1 & FML 28179 \\
\hline
\end{tabular}


TABLE 1 (Continued)

\begin{tabular}{|c|c|c|c|}
\hline Cleared and stained species & Stages & $N$ & Specimen number \\
\hline \multirow[t]{7}{*}{ Scinax acuminatus } & Adult & 2 & FML00248-41, LGE 10534 \\
\hline & $27-30$ & 6 & FML 28182 \\
\hline & $31-32$ & 2 & FML 28182 \\
\hline & $34-37$ & 7 & FML 28182 \\
\hline & $38-41$ & 3 & FML 28182 \\
\hline & 42 and 43 & 2 & FML 28182, FML 28183 \\
\hline & 46 & 2 & FML 28182 \\
\hline \multirow[t]{6}{*}{ Scinax fuscovarius } & Adult & 4 & FML 28133, FML 28134, FML 28135 \\
\hline & $26-30$ & 7 & FML 28176 \\
\hline & $34-37$ & 6 & FML 28176 \\
\hline & $38-41$ & 6 & FML 28176 \\
\hline & $42-44$ & 6 & FML 28176, FML 28177 \\
\hline & 45 and 46 & 2 & FML 28177 \\
\hline \multirow[t]{6}{*}{ Scinax sp. } & $29-30$ & 3 & FML 29939 \\
\hline & $31-33$ & 3 & FML 29939, FML 29940 \\
\hline & $34-37$ & 7 & FML 29941 \\
\hline & $38-40$ & 3 & FML 29941 \\
\hline & $42-44$ & 6 & FML 29941 \\
\hline & 45 & 1 & FML 29940 \\
\hline \multirow[t]{5}{*}{ Trachycephalus typhonius } & Adult & 3 & FML 28143, FML 28145, FML 2814 \\
\hline & 36 & 1 & FML 29435 \\
\hline & $38-41$ & 5 & FML 29435 \\
\hline & 42 & 1 & FML 29436 \\
\hline & 46 & 3 & FML 29436, FML 29440 \\
\hline
\end{tabular}

Institutional abbreviations: $\mathrm{DB}=$ Diego Baldo; FML = Fundación Miguel Lillo collection; LGE = Laboratorio de Genética Evolutiva collection, Posadas, Misiones, Argentina; $\mathrm{MCN}=$ Museo de Ciencias Naturales de la Universidad Nacional de Salta collection, Salta, Argentina; MLP = Museo de la Plata collection, La Plata, Buenos Aires, Argentina

3. Initial endochondral ossification of pectoral girdle: (0) Larval III; (1) Larval IV.

4. Initial endochondral ossification of pelvic girdle: (0) Larval III; (1) Larval IV.

5. Initial dermal ossification of pectoral girdle: (0) Larval III; (1) Larval IV.

6. Initial differentiation of articulation between pectoral girdle and axial skeleton: (0) Larval III; (1) Larval IV; (2) Early metamorphic.

7. Initial differentiation of articulation between pelvic girdle and axial skeleton: (0) Larval III; (1) Larval IV; (2) Early metamorphic.

8. Initial contact between halves of pectoral girdle: (0) Larval IV; (1) Early metamorphic.

9. Initial contact between halves of pelvic girdle: (0) Larval IV; (1) Early metamorphic.

10. Complete differentiation of ventromedial region of pectoral girdle: (0) Early metamorphic; (1) Late metamorphic.
11. Complete differentiation of ventromedial region of pelvic girdle: (0) Larval IV; (1) Early metamorphic; (1) Late metamorphic.

12. Complete differentiation of pelvic girdle-axial skeleton articulation: (0) Early metamorphic; (1) Late metamorphic.

13. Complete differentiation of the pectoral girdle-axial skeleton articulation: (0) Larval III; (1) Larval IV; (2) Early metamorphic.

14. Number of endochondral bones of the girdles: (0) Same number in both girdles.

15. Number of dermal bones of the girdles: (0) Two in the pectoral, none in the pelvic girdle.

16. Number of cartilaginous elements of the girdles: (0) Five pectoral, none pelvic; (1) Four pectoral, none pelvic; (2) Five pectoral, one pelvic.

17. Number of visible sutures of the girdles: (0) None pectoral, none pelvic; (1) Two pectoral, one pelvic; (2) Two pectoral, none pelvic. 
TABLE 2 Name equivalences, origin and insertion of the muscles of the pectoral girdle, and correspondent primaxial (light gray files) and abaxial (dark gray files) domains

\begin{tabular}{|c|c|c|c|c|}
\hline $\begin{array}{l}\text { Muscles (Duellman \& } \\
\text { Trueb, 1986; Manzano, } \\
\text { 1997) }\end{array}$ & $\begin{array}{l}\text { Muscles (Abdala \& } \\
\text { Diogo, 2010; Diogo } \\
\text { \& Ziermann, 2014) }\end{array}$ & $\begin{array}{l}\text { Origin (Duellman } \\
\text { \& Trueb, 1986; } \\
\text { Manzano, 1997) }\end{array}$ & $\begin{array}{l}\text { Origin (Abdala \& } \\
\text { Diogo, 2010; } \\
\text { Diogo \& Ziermann, } \\
\text { 2014) }\end{array}$ & Insertion \\
\hline Serratus superior & Serratus anterior & Vertebra III & Vertebra III & Suprascapula \\
\hline Serratus medius & Serratus anterior & Vertebra III & Vertebra III & Suprascapula \\
\hline Serratus inferior & Serratus anterior & Vertebra IV & Vertebra III & Suprascapula \\
\hline $\begin{array}{l}\text { Levator scapulae } \\
\text { inferior }\end{array}$ & Levator claviculae & Operculum & Opercular region & Suprascapula \\
\hline $\begin{array}{l}\text { Levator scapulae } \\
\text { superior }\end{array}$ & $\begin{array}{l}\text { Levator scapulae } \\
\text { superior }\end{array}$ & Vertebra I & Opercular region & Suprascapula \\
\hline Opercularis & Opercularis & & Opercular region & Suprascapula \\
\hline Cucullaris & Cucullaris & Otic process squamosal & Otic process squamosal & Scapula \\
\hline Rhomboideus posterior & Rhomboideus & & Vertebrae III and IV & Suprascapula \\
\hline Rhomboideus anterior & Rhomboideus occipitalis & $\begin{array}{l}\text { Otoccipital, } \\
\text { frontoparietal }\end{array}$ & Otoccipital & Suprascapula \\
\hline Omohyoideus & & Vertebra III-IV & Hyoid body & Scapula \\
\hline Dorsalis scapulae & Deltoideus scapularis & Scapula-Suprascapula & Suprascapula & Humerus \\
\hline $\begin{array}{l}\text { Dorsalis scapulae } \\
\text { inferior (d.s.i.) }\end{array}$ & Deltoideus scapularis & Suprascapula & Suprascapula & Deltoid crest humeral \\
\hline Deltoideus & $\begin{array}{l}\text { Procoracohumeralis. } \\
\text { (pars episternalis, pars } \\
\text { clavicularis, pars } \\
\text { scapularis) }\end{array}$ & $\begin{array}{l}\text { Procoracoid, } \\
\text { epicoracoid }\end{array}$ & $\begin{array}{l}\text { Omosternum, claviclae, } \\
\text { scapula and } \\
\text { precoracoid }\end{array}$ & Humerus \\
\hline Interscapularis & - & Scapula & Scapula & Suprascapula \\
\hline Pectoralis $^{a}$ & $\begin{array}{l}\text { Pectoralis. (pars epicor- } \\
\text { acoidea, pars sterna- } \\
\text { lis, pars abdominalis) }\end{array}$ & $\begin{array}{l}\text { Coracoid, sternum, m. } \\
\text { rectus abdominis }\end{array}$ & $\begin{array}{l}\text { Epicoracoid cartilage, } \\
\text { sternum, rectus } \\
\text { abdominis }\end{array}$ & Humerus \\
\hline Subscapularis ${ }^{a}$ & Subcoracoscapularis & - & $\begin{array}{l}\text { Medial portion of the } \\
\text { pectoral girdle }\end{array}$ & Humerus \\
\hline Coracoradialis & Supracoracoideus & $\begin{array}{l}\text { Procoracoid, } \\
\text { epicoracoid, clavicle }\end{array}$ & $\begin{array}{l}\text { Ventromedial surface } \\
\text { of the pectoral girdle }\end{array}$ & Humerus \\
\hline Coracoradialis & Coracoradialis & $\begin{array}{l}\text { Procoracoid, } \\
\text { epicoracoid, clavicle }\end{array}$ & $\begin{array}{l}\text { Ventromedial surface } \\
\text { of the pectoral girdle }\end{array}$ & Humerus \\
\hline Triceps brachii ${ }^{\mathrm{a}}$ & $\begin{array}{l}\text { Triceps brachii. (triceps } \\
\text { scapularis medialis, } \\
\text { triceps humeralis la- } \\
\text { teralis and triceps hu- } \\
\text { meralismedialis) }\end{array}$ & - & $\begin{array}{l}\text { Scapula, humerus, } \\
\text { medial and medial } \\
\text { humerus }\end{array}$ & Radio-ulna \\
\hline Coracobrachialis $^{a}$ & Coracobrachialis & Coracoid, glenoid cavity & Coracoid & Humerus \\
\hline
\end{tabular}

${ }^{a}$ Muscles not identified in this work.

18. Number of primaxial domain elements of the adult girdles: (0) pectoral $>$ pelvic

19. Number of abaxial domain elements of the adult girdles: (0) pectoral $>$ pelvic.

20. Appearance of mesenchymal condensations of the pectoral girdle: (0) Larval III; (1) Larval IV.

21. Appearance of pre-myogenic masses of the pectoral girdle: (0) Larval III; (1) Larval IV.
22. Appearance of pre-myogenic masses of the pelvic girdle: $(0)$ Larval III; (1) Larval IV.

23. Appearance of muscular masses of the pectoral girdle: (0) Early metamorphic; (1) Late metamorphic.

24. Appearance of muscular masses of the pelvic girdle: (0) Early metamorphic; (1) Late metamorphic

25. Appearance of the pre-tendon of the pectoral girdle: (0) Early metamorphic; (1) Late metamorphic. 
TABLE 3 Origin and insertion of the muscles of the pelvic girdle, and correspondent primaxial (light gray files) and abaxial domains (dark gray files)

\begin{tabular}{|c|c|c|c|}
\hline $\begin{array}{l}\text { Muscles (sensu Přikryl } \\
\text { et al., 2009) }\end{array}$ & $\begin{array}{l}\text { Muscles (sensu Diogo \& } \\
\text { Molnar, 2014) }\end{array}$ & Origin & Insertion \\
\hline Iliolumbaris & & Presacral vertebrae & Ilium \\
\hline Coccygeoiliacus & & Urostyle & Ilium \\
\hline Iliacus externus & Puboischiofemoralis internus B & llium & Femur \\
\hline Iliacus internus & Puboischiofemoralis internus $A$ & Ilium & Femur \\
\hline Gluteus maximus & Extensor iliotibialis B & Ilium & Cruralis (knee) \\
\hline Cruralis & Cruralis & llium & Aponeurosis (knee) \\
\hline Iliofemoralis & Iliofemoralis & llium & Femur \\
\hline Abductor longus & Puboischiofemoralis externus B & Ilium and pubis & Femur \\
\hline Pectineus & Puboischiofemoralis externus A & Ischium & Femur \\
\hline Adductor magnus & Adductor femoris & Ischium & Femur \\
\hline Obturador externus & Ischiotrochantericus B & Ischium & Femur \\
\hline Obturador internus & Ischiotrochantericus D & Ischium & Femur \\
\hline Quadratus femoris & Ischiotrochantericus C & Ischium & Femur \\
\hline Gemellus & Ischiotrochantericus A & Ischium & Femur \\
\hline Semimembranosus & Ischioflexorius & Ilium and Ischium & Aponeurosis (knee) \\
\hline Semitendinosus & Pubotibialis B & Ischium & Aponeurosis (knee) \\
\hline Gracilis major & Gracilis major & Ischium & Aponeurosis (knee) \\
\hline Gracilis minor & Gracilis minor & Ischium & Aponeurosis (knee) \\
\hline Iliofibularis & Tenuissimus & Ilium & Fibula \\
\hline Sartorius & Pubotibialis A & Ischium & Tibia \\
\hline Tensor fasciae latae ${ }^{a}$ & Extensor iliotibialis A & Ilium & Fasciae latae \\
\hline
\end{tabular}

The tensor fasciae latae muscle inserts in the $\mathrm{m}$. cruralis, which connects the ilium and knee aponeurosis.

a Muscle not identified in this work.

26. Appearance of the pre-tendons of the pelvic girdle: (0) Early metamorphic; (1) Late metamorphic.

Four of the included characters: 14, 15, 18, and 19 present just one character state in all taxa but we decided to include them to highlight their extreme conservatism.

\section{3 | RESULTS}

The developmental patterns of the pectoral and pelvic girdles of Lysapsus limellum in comparison with other anuran species are described. We selected L. limellum to perform our descriptions because it exhibits the most complete series.

\subsection{Skeletal description of Lysapsus limellum based on cleared and stained specimens}

\subsection{1 | Pectoral girdle}

Stage 32: Each half of pectoral girdle represented by a single cartilaginous element.
Stage 34: Initial chondrification of procoracoid, scapula, and coracoid.

Stage 35: Suprascapula present.

Stage 39: Initial ossification of scapula, coracoid, clavicle, and cleithrum. Anterolateral edge of suprascapula begins to differentiate; anterodistal projection present.

Stage 42: Both halves of pectoral girdle in contact.

Stage 43: Chondrification of sternum from two centers, and chondrification of omosternum begins (Figure 2a).

Stage 46: Sternum bifurcate.

Adult: Ossification of clavicle, cleithrum, coracoid, and scapula complete; suprascapula, procoracoid, epicoracoid, and omosternum cartilaginous (Figure $2 \mathrm{~b}, \mathrm{~g}, \mathrm{~h}$ ).

Interspecific variations

Differentiation of the suprascapula begins in Stage 34 in Scinax acuminatus, whereas in S. fuscovarius it begins in Stage 36. Chondrification of the coracoid begins in Stage 35 in S. fuscovarius and Phyllomedusa sauvagii, whereas in S. acuminatus, this occurs in Stage 37. 

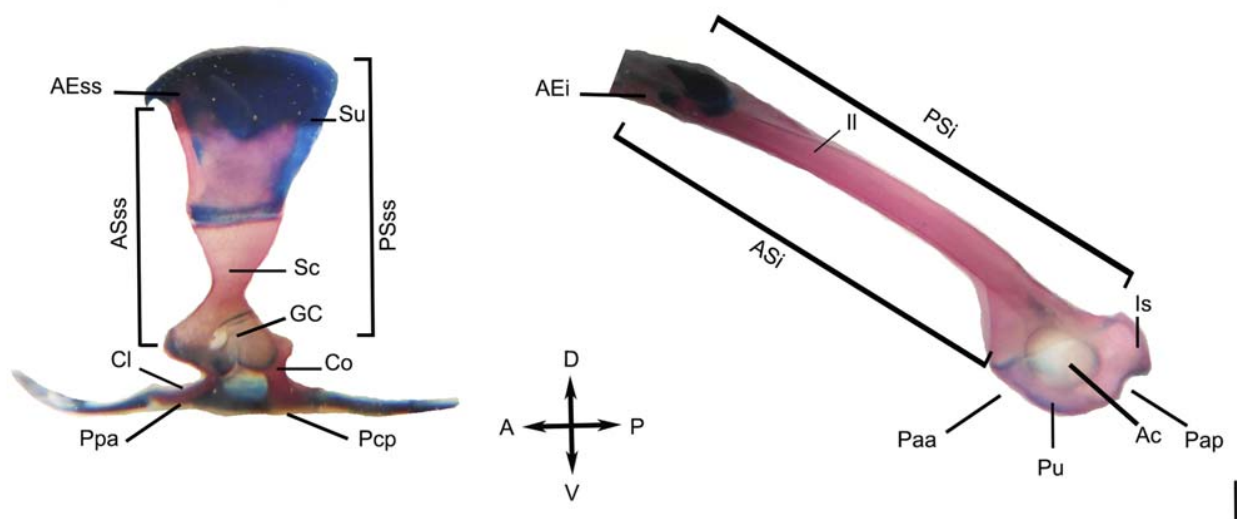

FIGURE 1 Lateral aspects of pectoral (left) and pelvic (right) girdles of an adult anuran of Scinax fuscovarius. The pectoral girdle retains most of the skeletal elements of the early tetrapods but the dermal elements (except the clavicle and cleithrum) tend to be reduced. Scale bar: $1 \mathrm{~mm} . \mathrm{A}=$ anterior; $\mathrm{Ac}=$ acetabulum; $\mathrm{AEi}=$ anterior end of the pelvic girdle, ilium anterior end; $\mathrm{AEss}=$ anterior end of the pectoral girdle, anterior end scapula-suprascapula; $\mathrm{ASi}=$ anterior surface of ilium;; ASss = Anterior Surface scapula-suprascapula; Co = coracoid; $\mathrm{Cl}$ = clavicle; $\mathrm{D}=$ dorsal; GC = glenoid cavity; II = ilium; Is = Ischium; $\mathrm{P}=$ posterior; Paa = posterior pelvic region, acetabular posterior region; $\mathrm{Pap}=$ posterior pelvic region, acetabular posterior region; $\mathrm{Pcp}=$ posterior of the pelvic hemigirdle region, coracoid posterior region; $\mathrm{Ppa}=$ Posterior pectoral region, procoracoidal anterior region; $\mathrm{PSi}=$ posterior surface of ilium; PSss $=$ posterior surface scapulasuprascapula; $\mathrm{Pu}=$ pubis; $\mathrm{Sc}=$ scapula; $\mathrm{Su}=$ suprascapula; $\mathrm{V}=$ ventral

The scapula ossifies in Stages 35 and 36 in Trachycephalus typhonius, Pithecopus azureus, and $P$. sauvagii. The coracoid ossifies in Stage 37 in T. typhonius, but in Stage 40 in P. sauvagii. The clavicle and cleithrum ossify simultaneously in Stage 37 in P. sauvagii, and in Stage 38 in P. azureus. The clavicle, cleithrum, coracoid, and scapula ossify in Stage 36 in Boana riojana and Phyllomedusa boliviana, but in Stage 37 in Scinax fuscovarius, S. acuminatus. In T. typhonius, the clavicle, cleithrum, and coracoid ossify in Stage 37.

The anterolateral edge of the suprascapula begins to differentiate in Stage 38 in Pithecopus azureus, Phyllomedusa boliviana, and Pseudis platensis. In Trachycephalus typhonius, this projection is visible in Stage 42; from Stages 42 to 44 , the morphology of the anterodistal region of the suprascapula acquires its typical adult shape. In Scinax acuminatus, the anterolateral edge of the suprascapula the adult configuration in Stage 36, but the anterodistal projection is not visible until Stage 40.

In Scinax acuminatus, the development of the sternum and the contact between the halves of the pectoral girdle begins in Stage 42. The sternum originates in Stage 42 in S. fuscovarius (Figure 2c), Scinax sp., Boana riojana, Phyllomedusa sauvagii, P. boliviana, and Pithecopus azureus (Figure 2e). The sternum originates from a single center of chondrification in S. fuscovarius (Figure 2c) and Scinax sp., whereas it originates from two centers to form a bifurcate element in P. azureus (Figure 2e). The sternum originates in Stage 42 in S. fuscovarius, Scinax sp., B. riojana, Phyllomedusa sauvagii, P. boliviana (Figure 2c,e), and Pithecopus azureus. When metamorphosis is complete, the posterior end of the sternum is not bifurcate in P. azureus (Figure 2f) and Scinax sp., whereas it is in S. fuscovarius (Figure 2 c) and postmetamorphically in B. riojana and Phyllomedusa sauvagii.

\subsection{2 | Pelvic girdle}

Stage 33: Two chondrification centers corresponding to ilium and ischium present.

Stage 36: Initial ossification of ilium.
Stage 39: Contact between halves of pelvic girdle established in area of ischium, and initial differentiation of posterior region of the pelvic girdle.

Stage 41: Halves of pelvic girdle united.

Stage 44: Anterior region of the ilium curved and rounded (Figure 3a).

Stage 45: Contact between ilium and sacrum established.

Stage 46: Initial ossification of ischium.

Adult: All pelvic bones ossified except anterior end of ilium (Figure 3b).

\section{Interspecific variation}

Contact between pelvic girdle halves in the area of the ischium level occurs in Stage 38 in Scinax fuscovarius, Scinax sp., Boana riojana, and Pithecopus azureus, but in Stage 40 or 41 in Phyllomedusa boliviana, S. acuminatus, Trachycephalus typhonius, and Phyllomedusa sauvagii. Initial differentiation of the posterior region of the pelvic girdle occurs in Stage 36-38 in B. riojana, P. boliviana, and Pseudis platensis.

The ischium begins to ossify in Stages 41 and 42 in Trachycephalus typhonius and Scinax acuminatus, respectively. In Boana riojana, ischial ossification occurs after metamorphosis. In Phyllomedusa boliviana, P. sauvagii, $B$. riojana, and T. typhonius, the anterior part of the ilium begins to curve in Stage 38-41 (Figure 3d). In P. boliviana and P. sauvagii, the anterior region of the ilium is acuminate, while in $P$. platensis, it is blunt (Figure 3c). In S. fuscovarius, P. boliviana, P. sauvagii, and Pithecopus azureus, contact between the ilium and sacrum occurs in Stage 42-44, whereas in S. acuminatus, this contact occurs at Stage 46 and in B. riojana, it occurs postmetamorphically.

\section{2 | Histology of the pectoral girdle of Lysapsus limellum}

Stage 37 (Figure 4a) 
(a)

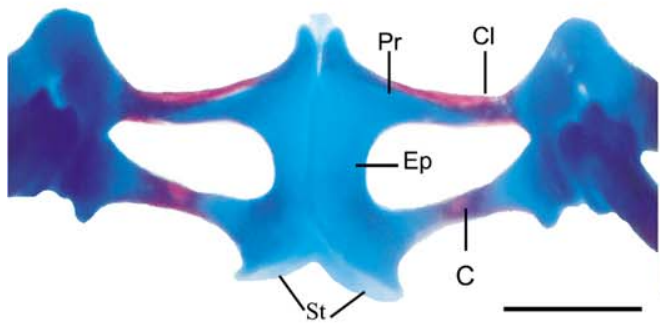

(c)

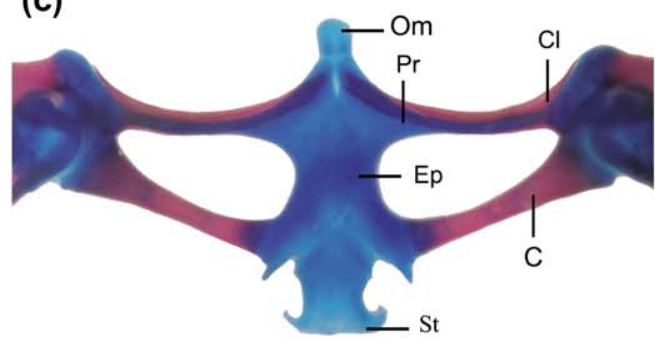

(e)

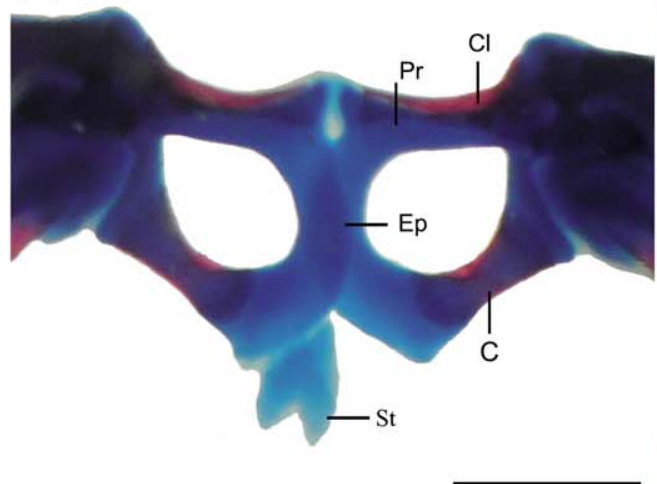

(g)

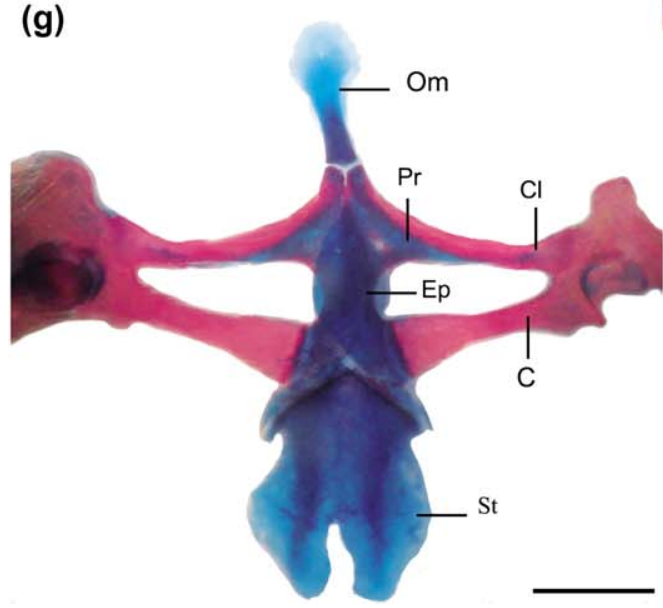

(b)
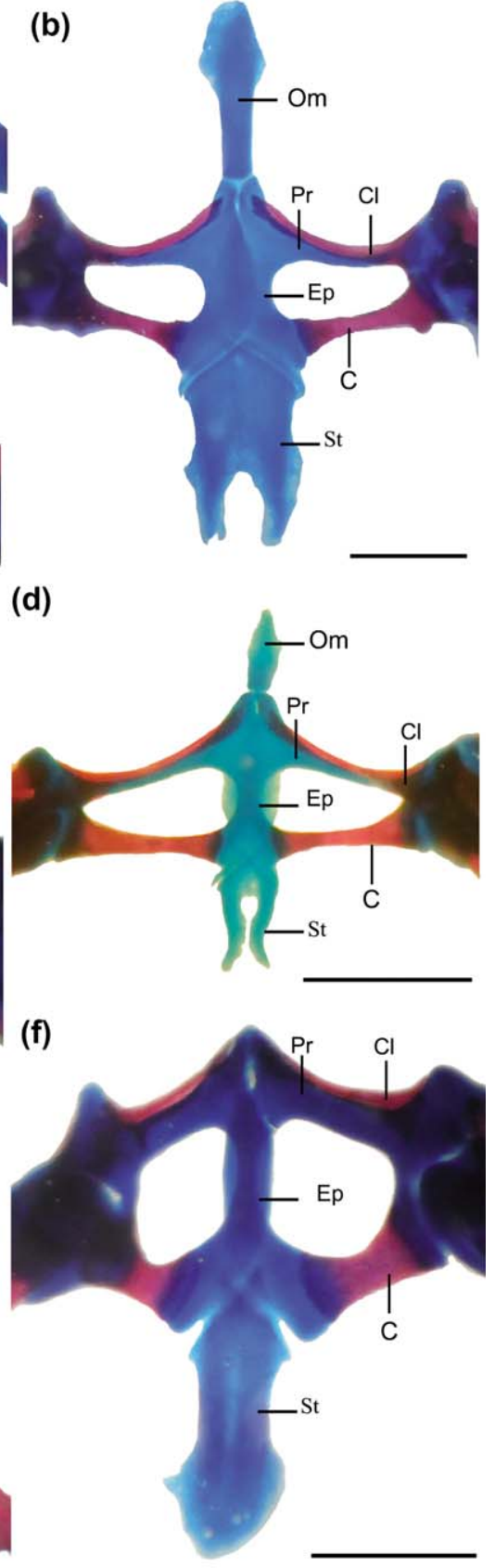

(h)

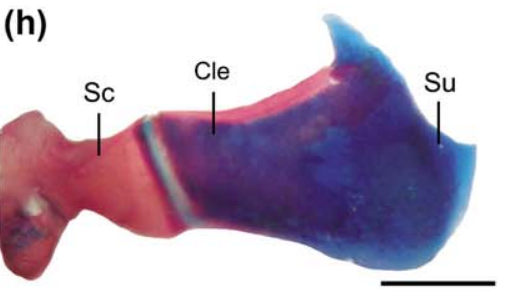

FIGURE 2 Developmental patterns of the pectoral girdle. (a, b, g, h) Lysapsus limellum. (a) Stage 43, (b) stage 46. (c, d) Scinax fuscovarius. (c) Stage 42, (d) stage 46. (e, f) Pithecopus azureus. (e) Stage 42, (f) stage 46. (g) Adult, ventral view, (h) adult, dorsal view. Scale bars: $1 \mathrm{~mm}$. C =coracoid; $\mathrm{Cl}=$ clavicle; $\mathrm{Cle}=$ cleitrum; $\mathrm{Ep}=$ epicoracoid; Om =omosternum; $\mathrm{Pr}=$ procoracoid; Sc =scapula; St =sternum; Su =suprascapula

Two mesenchymal condensations in the scapula-suprascapula region, may give rise to the serratus muscles. On the anterior surface of the dorsomedial portion of the suprascapulae, there are five premyogenic masses that may represent the levator claviculae, levator scapulae superior, rhomboideus, rhomboideus occipitalis muscles, and cucullaris. There are two mesenchymal condensations that represent the interscapularis and serratus anterior. The two pre-myogenic masses located on the dorsal and posterior surfaces of the suprascapula 


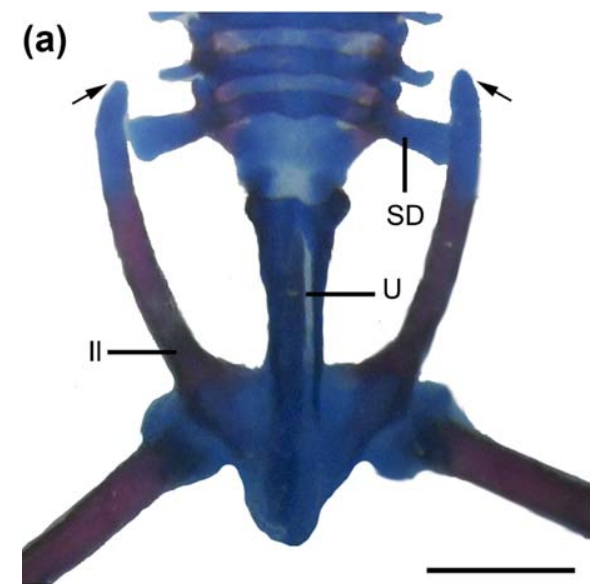

(b)
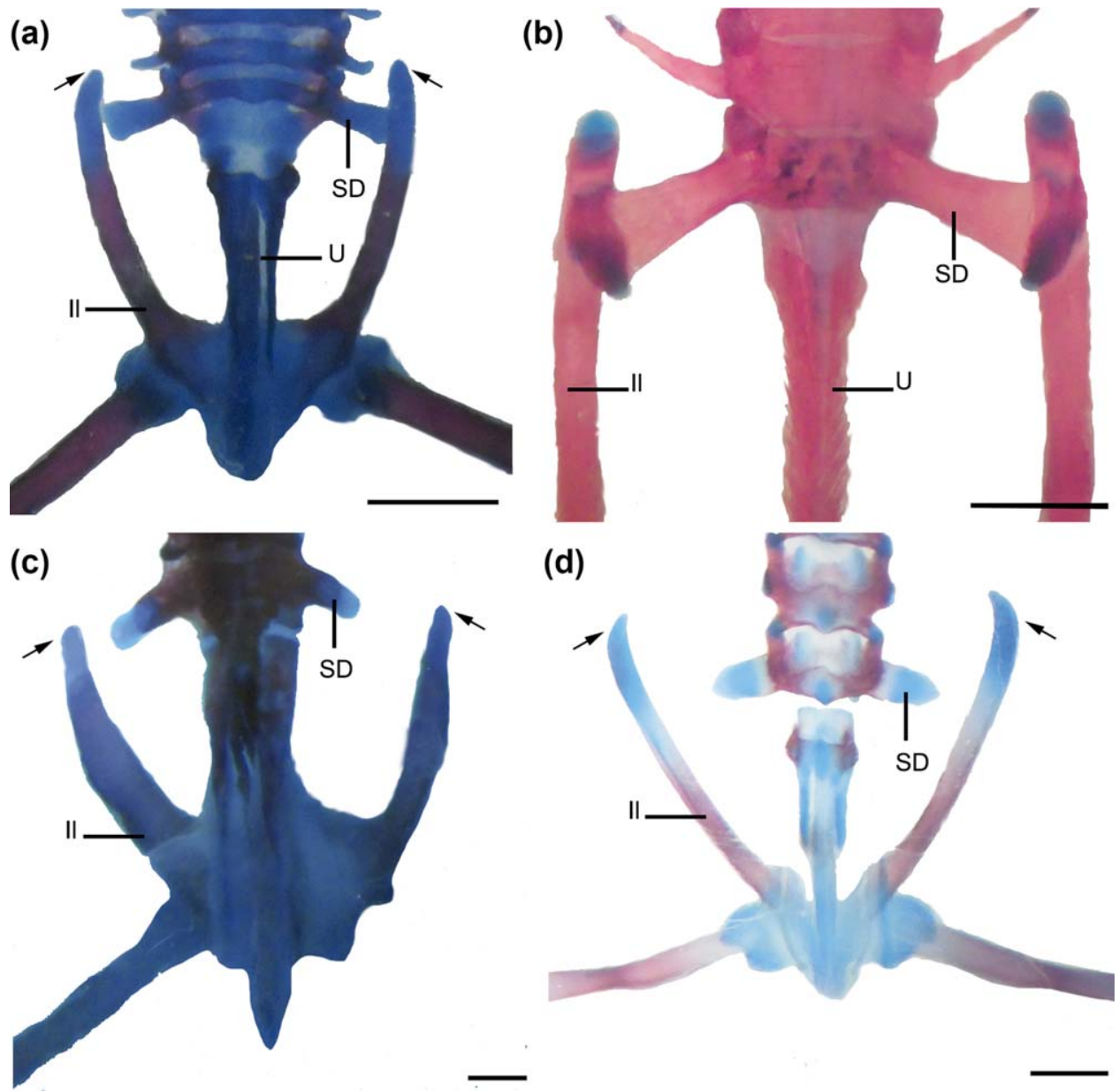

(d)

FIGURE 3 Developmental patterns of the pelvic girdle. (a, b) Lysapsus limellum. (a) Stage 44, (b) Adult. (c) Pseudis platensis. Stage 43. (d) Plyllomedusa sauvagii. Stage 40 . Note the variability of the anterior end of the ilium (arrows). Scale bars: $1 \mathrm{~mm}$. II =ilium; SD =sacral diapophyses; $U$ = urostyle

correspond to the presumptive branches of the deltoideus scapularis. The insertion of this muscle defines the boundary between the scapula and the suprascapula, which are represented by a single cartilaginous element composed of mature chondrocytes. A mesenchymal condensation occurs at the future insertion of the deltoideus scapularis superior muscle at the level of the interzone between the scapula and suprascapula. In the posteroventral region, there are five pre-myogenic muscular masses. One may correspond to the procoracohumeralis muscle, whereas the others could not be identified. The cartilaginous procoracoids are continuous with the scapula, the boundaries of which could not be defined.

Stage 40 (Figure $4 b, c$ )

At the anteromedial end of the dorsal region of the scapulasuprascapula, two pre-myogenic masses that might correspond to the serratus anterior muscles are found (Figure 4b). On the anterior surface of the dorsomedial portion of the suprascapular, there are premyogenic masses with two visible sites of origin. These masses may represent the deltoideus scapularis and interscapularis muscles. The proximal cartilaginous area corresponding to the scapula is composed of hypertrophic chondrocytes. The ossification of the cleithrum is evident in the suprascapular region. In the cleithrum, the osteocytes are surrounded by a bony extracellular matrix with trabeculae with the spaces between the trabeculae containing blood vessels. Three premyogenic masses that probably correspond to the branches of the deltoideus scapularis muscle and to the procoracohumeralis muscle are located in the posteroventral region. The girdle halves are close to each other, and ligamentous connective tissue occurs between the procoracoids (Figure 4c).

Stage 44 (Figure 4d,e)

At the anteromedial end of the dorsal region of the suprascapula, there are three muscle masses that may correspond to the branches of the serratus anterior and rhomboideus muscles (Figure 4d). On the posterior surface of the suprascapula, two muscle masses representing the branches of the deltoideus scapularis are found. In the scapular region, adjacent to the glenoid cavity, the cartilage is formed by hypertrophic chondrocytes surrounded by a thin layer of periostic bony tissue and abundant blood vessels. The cleithrum is formed by thin layers of bone and osteocytes, and a large area with abundant blood vessels (Figure 4d). In the posteroventral region, there is one unidentified muscular mass. The cartilaginous procoracoids overlap slightly and are connected by a ligamentous connective tissue. The pars clavicularis of the procoracohumeralis is identified. The clavicle is ossified, with osteocytes surrounded by a bony extracellular matrix (Figure 4e). 

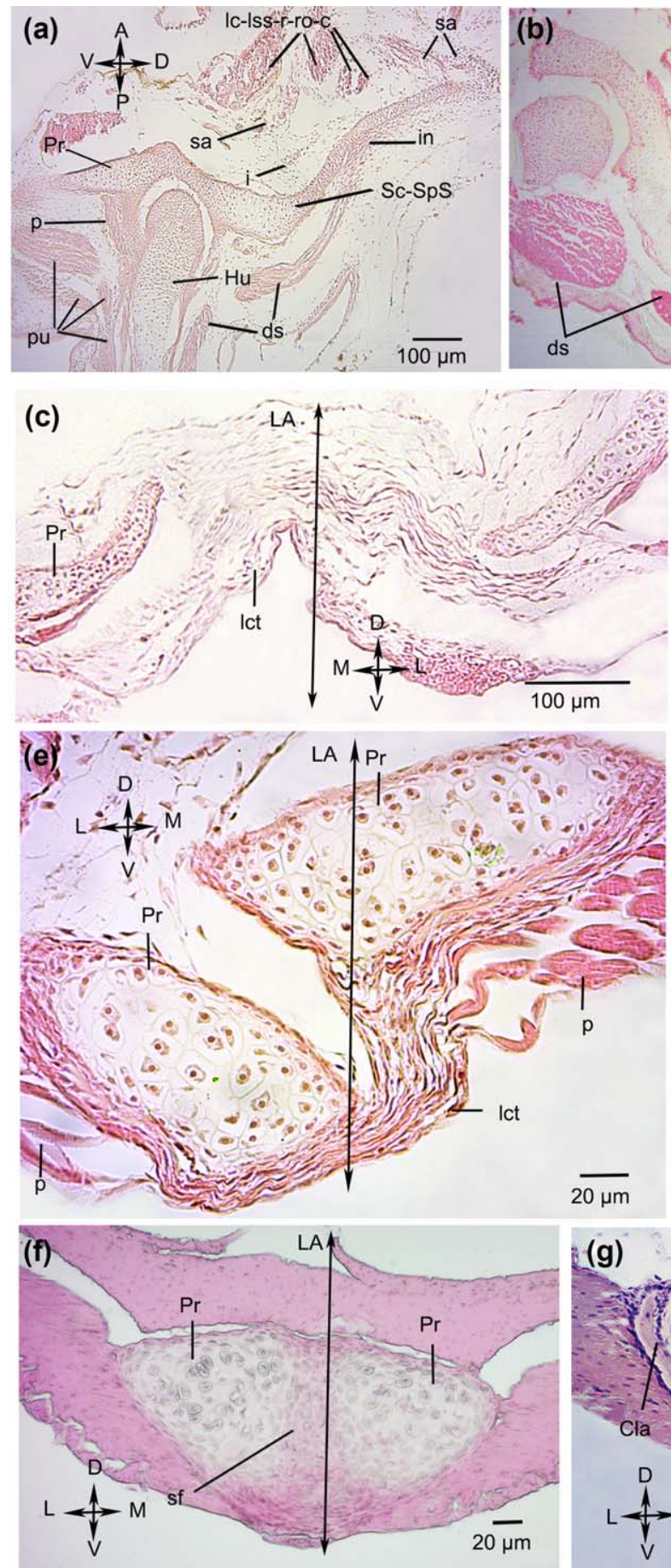
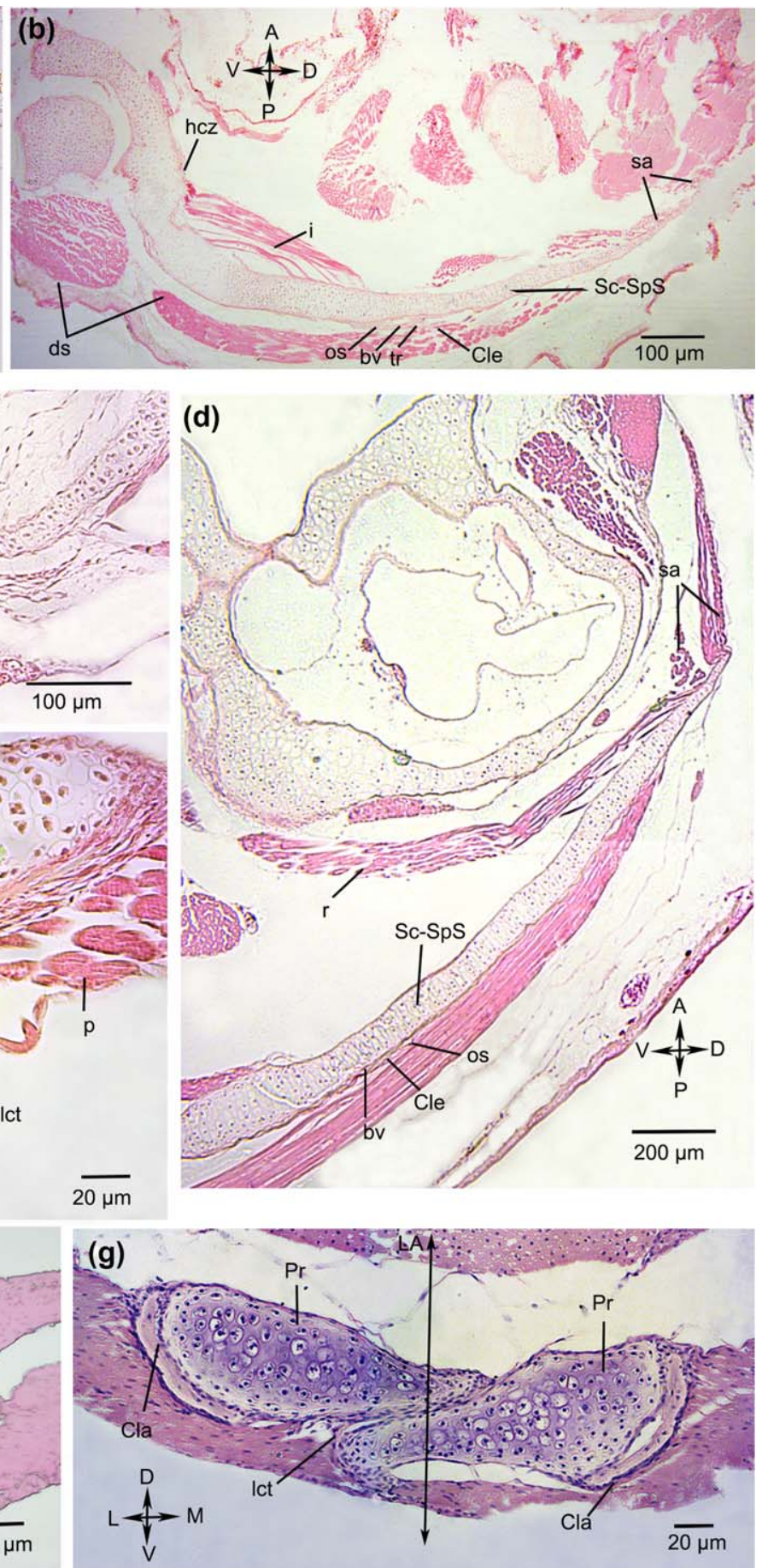

FIGURE 4 Tissue development of the pectoral girdle of Lysapsus limellum. (a) Stage 37, (b, c) stage 40, (d, e) stage 44, (f, g) stage 46. Note the differences in the muscles elements of the primaxial and abaxial regions, the organized ligamentous tissue between both girdle halves (e), and the synchondrotic fusion between both procoracoids (f). $\mathrm{A}=$ anterior; $\mathrm{bv}=$ blood vessel; $\mathrm{c}=$ cucullaris; $\mathrm{Cla}=$ clavicle; $\mathrm{Cle}=\mathrm{cleithrum;} \mathrm{D}=\mathrm{dorsal}$; ds = deltoideus scapularis superior; $\mathrm{hcz}=$ hypertrophic chondrocytes zone; $\mathrm{Hu}=$ humerus; $\mathrm{i}=$ interescapularis; in = interzone; $\mathrm{L}=$ lateral; $\mathrm{LA}=$ longitudinal axis; Ic = levator claviculae; Ict = ligamentous connective tissue; Iss = levator scapulae superior; $M=$ medial; os = osteocyte; $\mathrm{P}=$ posterior; $\mathrm{p}$ = procoracohumeralis; $\mathrm{Pr}=$ procoracoid; $\mathrm{pu}=$ pre-myogenic masses unidentifiable; $\mathrm{r}=$ rhomboideus; $\mathrm{ro}=$ rhomboideus occipitalis; $\mathrm{sa}=$ serratus anterior; $\mathrm{Sc}-\mathrm{SpS}=$ scapula-suprascapula; $\mathrm{sf}=$ synchondrotic fusion; $\mathrm{tr}=$ trabeculae; $\mathrm{V}=$ ventral

\section{Stage 46 (Figure 4f,g)}

At the anteromedial end of the dorsal region of the suprascapula, there are four muscle masses that may correspond to the branches of the future serratus anterior, rhomboideus occipitalis, and rhomboideus muscles. On the anterior surface of the dorsomedial portion of the suprascapula, there are five muscle masses that may represent the levator scapulae inferior, levator scapulae superior, cucullaris, rhomboideus occipitalis, and rhomboideus muscles. 
At the edge of the glenoid cavity, the scapula has pre-tendinous tissue. Two muscle masses representing the branches of the deltoideus scapularis are on the posterior surface of the suprascapula. Posteroventrally there are three muscle masses; one may correspond to the procoracohumeralis, but the others could not be identified. The procoracoids are synchondrotically fused at the anterior cartilaginous ends (Figure 4f). In the most posterior region, the procoracoids overlap slightly and are united by ligamentous connective tissue. The clavicle is composed of osteocytes in lacunae and extracellular matrix (Figure 4g).

\subsubsection{Interspecific variation in the developmental pattern}

Boana riojana

Stage 41 (Figure 5a)

Six pre-myogenic masses occur on the anterior surface of the dorsomedial portion of the suprascapula; one may correspond to the levator claviculae, and the others to the levator scapulae superior, cucullaris, rhomboideus occipitalis, rhomboideus, and omohioideus. The scapula has a zone of hypertrophic chondrocytes surrounded by a thin layer of periostic osseous tissue, with small trabeculae and blood vessels. In the posteroventral region, there are two unidentifiable premyogenic masses. At the edges of the procoracoids, a thin layer of bone corresponding to the clavicle, formed by osteocytes and a bony extracellular matrix is evident. Ligamentous connective tissue separates the procoracoids.

Stage 44 (Figure 5b)

Two pre-myogenic masses lie at the anteromedial end of the dorsal region of the suprascapula, which may be the branches of the future serratus anterior muscle. On the anterior surface of the dorsomedial portion of the suprascapula, five pre-myogenic masses, may correspond to the levator claviculae and levator scapulae superior, cucullaris, rhomboideus occipitalis, and rhomboideus muscles. One pre-myogenic mass corresponding to the deltoideus scapularis muscles occurs on the posterior surface of the suprascapula. Posteroventrally, there are four muscle masses. Two may correspond to the procoracohumeralis, one to the coracoradialis, and one is unidentifiable. The cartilaginous procoracoids do not overlap. In the clavicle, osteocytes are surrounded by gaps in a bony extracellular matrix.

\section{Phyllomedusa sauvagii}

Stage 36 (Figure 5c,d)

No mesenchymal condensations or pre-myogenic masses are present at the anteromedial end of the dorsal region of the scapulasuprascapula. On the anterior surface of the dorsomedial portion of the scapula-suprascapula, there is one mesenchymal condensation that may represent the interscapularis muscle. The scapular cartilage at the edge of the glenoid cavity is surrounded by a thin layer of periostic osseous tissue. In the region of the suprascapula, the cleithrum is formed by osteocytes in lacunae, and a bony extracellular matrix is evident. Two pre-myogenic masses representing the branches of the deltoideus scapularis are located on the posterior surface of the suprascapular.

Stage 38 (Figure 5e)
At the anteromedial end of the dorsal region of the scapulasuprascapula, two pre-myogenic masses, may represent the branches of the serratus anterior. On the anterior surface of the dorsomedial portion of the scapula-suprascapula, three pre-myogenic masses and three mesenchymatic condensations are present. These may give rise to the levator scapulae superior, cucullaris, rhomboideus occipitalis and rhomboideus, interescapularis, and serratus anterior, respectively. Posteroventrally, there are three pre-myogenic condensations; one may represent the procoracohumeralis, but the others could not be identified.

Boana riojana and Phyllomedusa sauvagii

Stage 46 (Figure $5 f, g$ )

Two muscle masses, possibly corresponding to the branches of the serratus anterior, are located at the anteromedial end of the dorsal region of the suprascapula. Six muscle masses that could correspond to the levator claviculae, levator scapulae superior, cucullaris, rhomboideus occipitalis, rhomboideus, and omohioideus are on the anterior surface of the dorsomedial part of the suprascapula. Endochondral ossification of the scapula is progressing, and a zone of hypertrophic chondrocytes surrounded by periostic bone tissue is present. The cartilage is disintegrating, and there is a large recess with blood vessels and bone marrow. At the posterodorsal edge of the suprascapula, the cleithrum is formed by osteocytes, a bony extracellular matrix and trabecular bone.

Posteroventrally, there are three muscle masses that may correspond to the procoracohumeralis, coracoradialis, and procoracohumeralis (pars clavicularis) (Figure 5f). The clavicle is composed of osteocytes surrounded by a bony extracellular matrix. The trabeculae are forming, with peripheral osteoblasts and blood vessels (Figure 5g).

\subsection{Histology of the pelvic girdle of Lysapsus limellum}

Stage 37 (Figure 6a,b)

The cartilaginous plate representing the ilium-ischium-pubis is formed by mature chondrocytes (Figure 6a). The medial border of the pubis lies at the mid-width of the acetabulum. In the acetabular region, posteroventral to the ilium, there are three pre-myogenic masses that may correspond to the future ischiotrochantericus $D$ (obturator internus), puboischiofemoralis externus B (adductor longus), and gracilis major. Two pre-myogenic masses occur on the posterodorsal surface of the ilium. One may represent the puboischiofemoralis externus $A$ (pectineus), and the other the puboischiofemoralis internus A (iliacus internus) extensor iliotibialis B (gluteus maximus) complex (Figure 6a). One pre-myogenic mass at the anterior end of the medial region of the ilium may give rise to the coccygeoiliacus (Figure 6b). Laterally, two pre-myogenic masses may correspond to the iliolumbaris and puboischiofemoralis internus $A$ (Figure 6b).

Stage 40 (Figure 6c)

The girdle halves are separated by dense connective tissue. The mature muscle tissue is well defined, has abundant nuclei, and is 

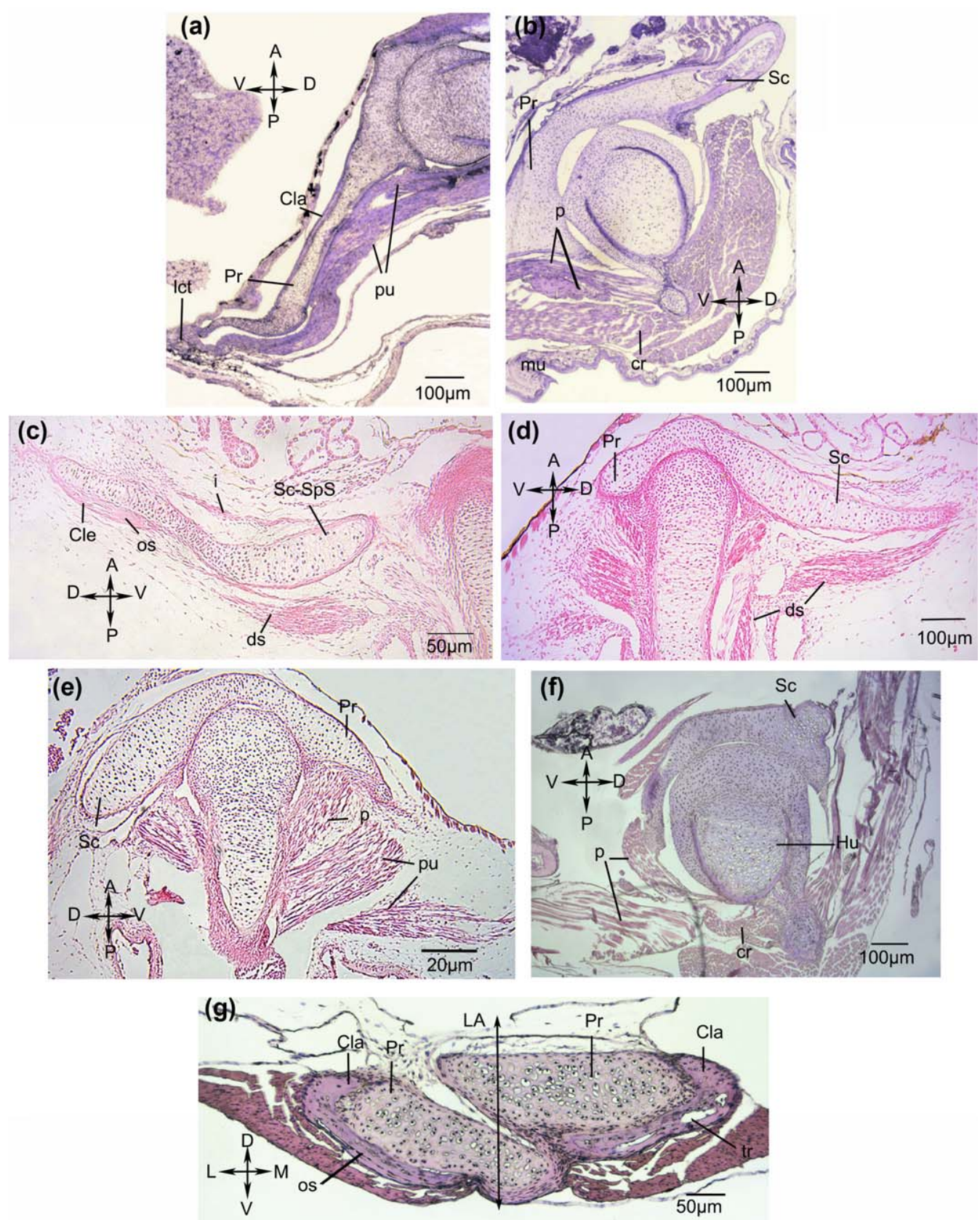

FIGURE 5 Tissue development of the pectoral girdle. All muscles in the Stages earlier than 44 are represented by one mesenchymal condensation and pre-myogenic tissues. (a, b, f) Boana riojana. (a) Stage 41, (b) stage 44, (f) stage 46. (c, d, e, g) Phyllomedusa sauvagii. (c) Stage 36 scapula-suprascapula region, (d) stage 36 glenoid region, (e) stage 38, (g) stage 46. A = anterior; Cla = clavicle; Cle = cleithrum; $\mathrm{cr}=$ coracoradialis; $\mathrm{D}=$ dorsal; $\mathrm{ds}=$ dorsalis scapulae; $\mathrm{Hu}=$ humerus; $\mathrm{L}=$ lateral; $\mathrm{LA}=$ longitudinal axis; Ict = ligamentous connective tissue; $\mathrm{M}=$ medial; $\mathrm{mu}=$ mass unidentifiable; os = osteocyte; $\mathrm{P}=$ posterior; $\mathrm{p}=$ procoracohumeralis; $\mathrm{Pr}=$ procoracoid; $\mathrm{pu}=$ pre-myogenic masses unidentifiable; $\mathrm{Sc}=$ scapula; $\mathrm{Sc}-\mathrm{SpS}=$ scapula-suprascapula; $\mathrm{tr}=$ trabeculae; $\mathrm{V}=$ ventral

formed by elongated fibers arranged in bundles. There is a pre-tendon at the anterior distal end. The articular cavity is slightly concave and poorly defined.

Stage 44 (Figure 6d)

The girdle halves are synchondrotically fused at the level of the ischium and ilium, and there is an abundant dense connective tissue at the level of the pubis. The articular cavity is more concave and the muscle masses larger and more compact than in Stage 40. In the acetabular region, specifically at the posteroventral region of the ischium, there are three muscle masses, that probably represent the ischiotrochantericus $\mathrm{D}$, puboischiofemoralis externus $\mathrm{B}$, and gracilis major.

\section{Stage 46 (Figure 6e)}

The ilium is composed of calcified cartilage. Hypertrophic chondrocyte and chondroblast zones are distinguishable. The muscular masses are more compact, with thicker and more numerous fibers than in Stage 44. The acetabular joint is clearly delimited. 

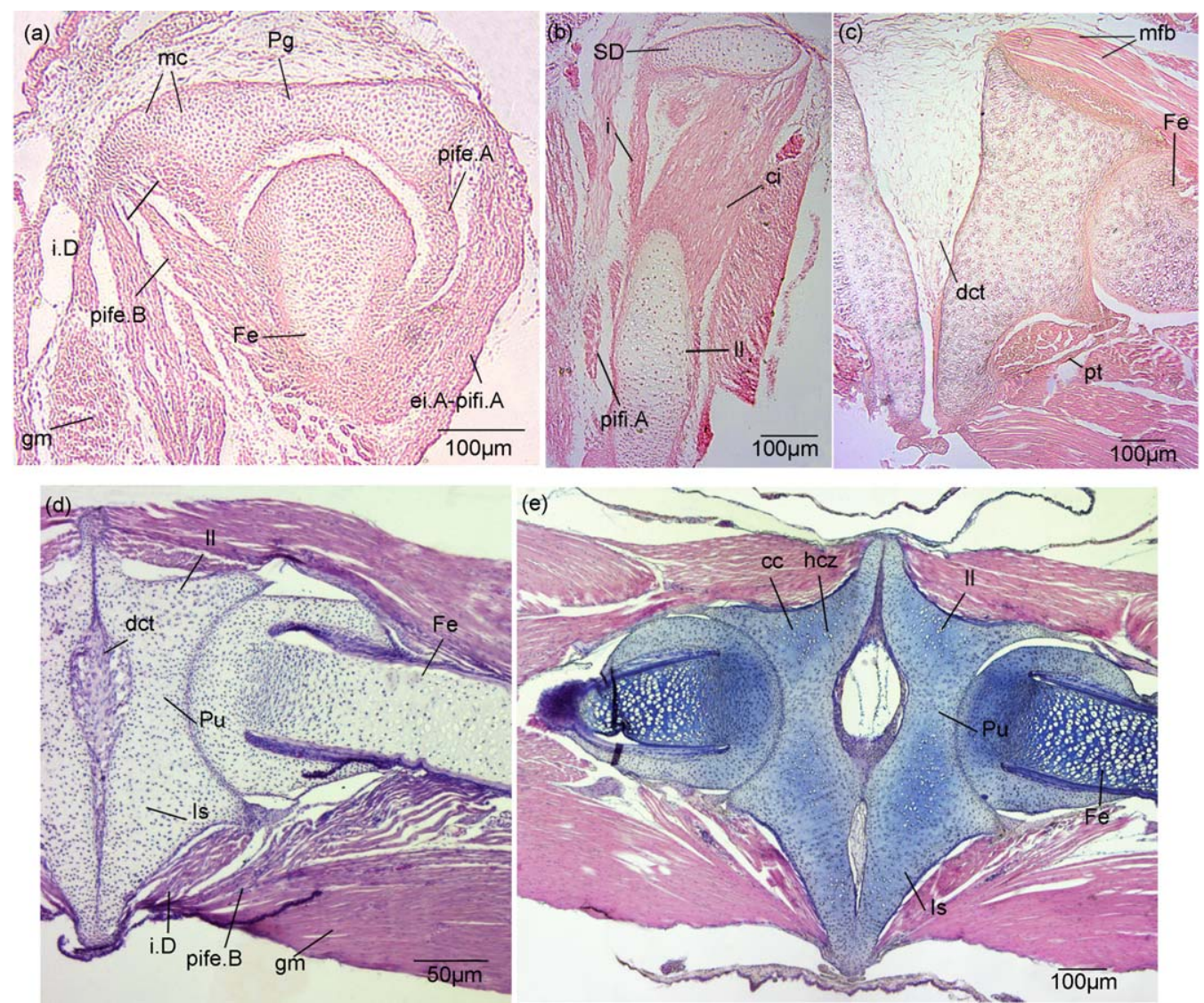

FIGURE 6 Tissue development of the pelvic girdle of Lysapsus limellum. All muscles are represented by pre-myogenic tissue. (a) Stage 37, acetabular region. (b) Stage 37, anterior region of the ilium. (c) Stage 40, acetabular region. (d) Stage 44, acetabular region. (e) Stage 46, acetabular

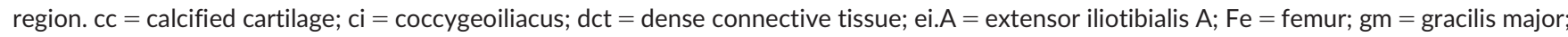
hcz = hypertrophic chondrocytes zones; $\mathrm{i}=$ iliolumbaris; i.D = Ischiotrochantericus D; II = ilium; Is = ischium; $\mathrm{mc}=$ mature chondrocytes; $\mathrm{mfb}=$ muscular fibers bundles; $\mathrm{Pg}=$ pelvic girdle; pife. $\mathrm{A}=$ puboischiofemoralis externus $\mathrm{A} ;$ pife. $\mathrm{B}$ = puboischiofemoralis externus $\mathrm{B}$; pifi. $\mathrm{A}=$ puboischiofemoralis internus $\mathrm{A} ; \mathrm{pt}=$ pre-tendon; $\mathrm{Pu}=$ pubis; $\mathrm{SD}=$ sacral diapophyses

\subsubsection{Interspecific variations in the developmental pattern}

\section{Boana riojana}

Stage 37 (Figure 7a)

The girdle halves are narrowly separated in the posterior part of the ischium. The medial border of the pubis at the mid-width of the acetabulum is concave. Immature muscle tissue is distinguishable. In the acetabular region, specifically on the posterodorsal surface of the ilium, there are two pre-myogenic masses; these may give rise to the puboischiofemoralis externus $A$ and the puboischiofemoralis internus $A$.

\section{Stage 41 (Figure 7b)}

The girdle halves are in full contact at the level of the pubis. The acetabulum is elongated and forms the acetabular cavity. The muscle tissue has abundant nuclei packages, surrounded by dense connective tissue, and consists of bundles of elongate fibers. A pre-tendon is present at the anterodistal end of the ilium. The articular cavity of the acetabulum is slightly concave, rather undefined, and contains abundant nuclei.

\section{Stage 44 (Figure 7c)}

There is a pre-tendon on the posterior part of the ischium and another one in the anterior region of the acetabulum. Mature muscle tissue with abundant compact nuclei is arranged in bundles of fibers. Each muscle mass is surrounded by dense connective tissue. The groove of the ischium is broader and deeper than in Stage 40. The acetabular cavity is not clearly defined.

Stage 46 (Figure 7d)

Calcified cartilage, hypertrophic chondrocytes, and zones of chondroblasts are present in the ilium. The muscle masses have become more compact, with thicker and more numerous fibers than in Stage 44. The acetabular joint is clearly delimited.

\section{Phyllomedusa sauvagii}

Stage 36 (Figure 7e)

The girdle halves are widely separated. The medial border of the pubis is slightly convex at the mid-width of the acetabular cavity. On the posterodorsal surface of the ilium, there are two pre-myogenic masses; these may give rise to the ischiotrochantericus $D$ and the puboischiofemoralis externus $A$ puboischiofemoralis internus $A$ complex.

\section{Stage 44 (Figure 7f,g)}

The girdle halves are synchondrotically fused at the level of the ischium and connected by dense connective tissue at the level of the pubis. A pre-tendon is present in the anterior region of the acetabulum. 

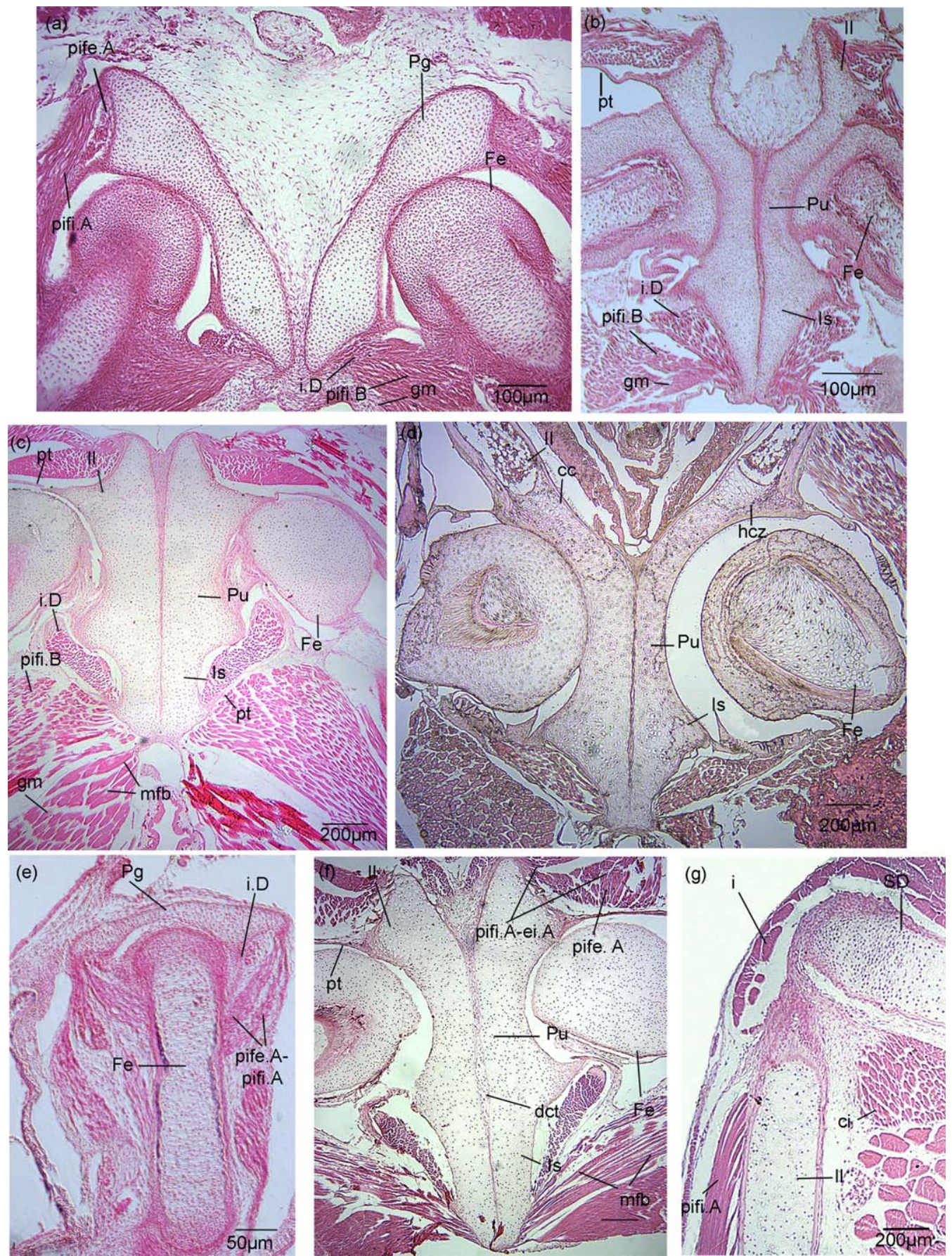

FIGURE 7 Tissue development of the pelvic girdle. All muscles except for the gracilis major are represented by pre-myogenic tissue. (a, d) Boana riojana. (a) Stage 37, (b) Stage 41, (c) Stage 44, (d) Stage 46. (e-g) Phyllomedusa sauvagii. (e) Stage 37, (f) Stage 44 acetabular region, (g) stage 44 anterior region of the ilium. Note the differences in the muscle elements in the primaxial and abaxial regions, and the highly compacted and disorganized tissue that fills the space between the girdle halves. The halves of the pelvic girdle are close together and almost completely connected synchondrotically. $\mathrm{cc}=$ calcified cartilage; $\mathrm{ci}=$ coccygeoiliacus; $\mathrm{dct}=$ dense connective tissue; ei.A = extensor iliotibialis $\mathrm{A}$; Fe = femur; gm = gracilis major; hcz = hypertrophic chondrocytes zones; $\mathrm{i}=$ iliolumbaris; i.D = ischiotrochantericus $\mathrm{D}$; II = ilium; Is = ischium; $\mathrm{mfb}=$ muscular fibers bundles; $\mathrm{Pg}=$ pelvic girdle; pife. $\mathrm{A}=$ puboischiofemoralis externus $\mathrm{A}$; pifi.A = puboischiofemoralis internus $\mathrm{A}$; pifi.B = puboischiofemoralis internus $\mathrm{B} ; \mathrm{pt}=$ pre-tendon; $\mathrm{Pu}=$ pubis; $\mathrm{SD}=$ sacral diapophyses

The mature muscle tissue is well defined, has abundant nuclei and arranged in bundles of elongate fibers. The acetabular cavity is poorly defined (Figure 7f). There are two muscle masses on the posterodorsal surface of the ilium; these may correspond to the puboischiofemoralis externus $A$, and the puboischiofemoralis internus
A-extensor iliotibialis muscular complex (Figure 7f). There is one muscle mass at the anterior end of the medial part of the ilium; this may correspond to the coccygeoiliacus. Laterally, the two muscle masses may give rise to the iliolumbaris and puboischiofemoralis internus A (Figure 7g). 
TABLE 4 Differences in osteological characters (number of bones) between the pectoral and pelvic girdles of anuran adults

\begin{tabular}{|c|c|c|}
\hline Adults & Pectoral girdle & Pelvic girdle \\
\hline $\begin{array}{l}\text { Number of } \\
\text { endochon- } \\
\text { dral bones }\end{array}$ & 2: Coracoid, scapula & $\begin{array}{l}\text { 2: Ilium, } \\
\text { ischium }\end{array}$ \\
\hline $\begin{array}{l}\text { Number of } \\
\text { dermal } \\
\text { bones }\end{array}$ & 2: Clavicle, cleithrum & - \\
\hline $\begin{array}{l}\text { Number of } \\
\text { cartilages }\end{array}$ & $\begin{array}{l}\text { 4-5: Suprascapula, } \\
\text { procoracoid, epicoracoid, } \\
\text { sternum, omosternum }\end{array}$ & $0-1:$ Pubis \\
\hline $\begin{array}{l}\text { Number of } \\
\text { joints }\end{array}$ & $\begin{array}{l}2 \\
\text { Scapula-Suprascapula } \\
\text { Glenoid: Scapula-coracoid, } \\
\text { scapula-clavicle/ } \\
\text { procoracoid }\end{array}$ & $\begin{array}{l}1 \\
\text { Acetabular: } \\
\text { Ilium-ischium, } \\
\text { ilium-pubis, } \\
\text { ischium-pubis }\end{array}$ \\
\hline
\end{tabular}

\subsection{Comparison of the pectoral and pelvic girdles}

The general anatomy, and osteological and histological developmental patterns of the girdles are compared. The anuran pectoral girdle is complex and composed of the suprascapula, scapula, cleithrum, procoracoid, coracoid, clavicle, epicoracoid, sternum, and omosternum (Figure 1; Table 2). The eight muscles that connect the axial skeleton to the pectoral girdle and are responsible for its movement are: serratus anterior, rhomboideus, rhomboideus occipitalis, levator scapulae superior, cucullaris, opercularis, and levator claviculae. Nine muscles connect the pectoral girdle to the forelimb: pectoralis, supracoracoideus, procoracohumeralis, deltoideus scapularis, subcoracoscapularis, triceps brachii, coracobrachialis, and coracoradialis (Table 2).

The anuran pelvic girdle is V-shaped. Posteriorly, the bones and cartilage fuse to form a disc-like structure. Each of the identical halves of the pelvic girdle is termed an "innominate" bone, which is formed by the ilium, ischium, and pubis (Figure 1; Table 3). The seven primary muscles that connect the axial skeleton to the pelvic girdle and are responsible for its movement are: iliofemoralis, tenuissimus, extensor iliotibialis A (tensor fasciae latae), extensor iliotibialis B, cruralis, puboischiofemoralis internus $A$, and puboischiofemoralis internus $B$ (iliacus externus). Nine muscles connect the pelvic girdle with the hindlimb: adductor femoris, pubotibialis A (sartorius) and B (semitendinosus), gracilis major, gracilis minor, ischioflexorius (semimembranosus), caudofemoralis (pyriformis), and ischiotrochantericus $\mathrm{A}$ and $\mathrm{B}$.

The pectoral girdle has nine skeletal elements, the pelvic girdle has only three (Table 4). Moreover, all pelvic girdle bones are endochondral. Four elements form the glenoid cavity of the pectoral girdle and only three form the acetabulum of the pelvic girdle. The pectoral girdle is mobile, the pelvic girdle is not.

Almost all the interspecific osteological differences involve the timing of the main developmental events (Figure 8). Differentiation of the

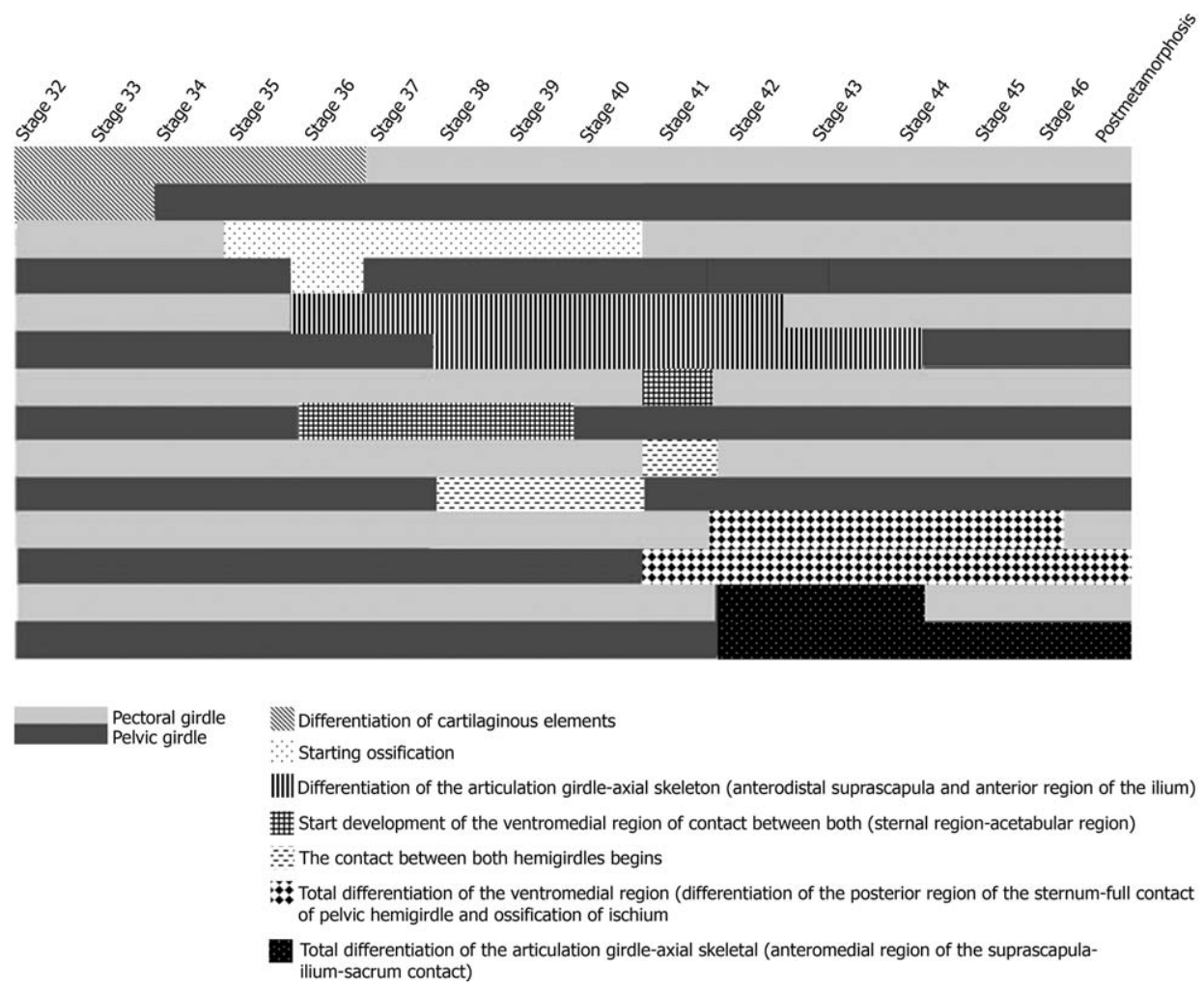

FIGURE 8 Timing of the main developmental events based on Gosner (1960) stages. Initial differentiation of the cartilaginous tissue, and total differentiation of the axial-girdle joints start synchronically. Ossification and formation of the axial-girdle joints in the pectoral girdle precede those of the pelvic girdle. Initial development of the ventromedial region and establishment of the contact between the halves of the pectoral girdle are not synchronous. The total differentiation of the ventromedial region takes more time in the pelvic girdle than in the pectoral girdle 
TABLE 5 Tissue development in anurans

\begin{tabular}{|c|c|c|c|c|c|c|c|}
\hline \multirow[t]{3}{*}{ Stage } & & \multicolumn{5}{|l|}{ Region } & \multirow[t]{3}{*}{$\begin{array}{l}\text { Relationship between } \\
\text { hemi-girdles }\end{array}$} \\
\hline & & \multicolumn{3}{|l|}{ Anterior } & \multicolumn{2}{|l|}{ Posterior } & \\
\hline & & AEss- AEi & AssS-ASi & PsS-PSi & Pcp-Pap & Ppa-Paa & \\
\hline \multirow[t]{2}{*}{$36-37$} & Pectoral girdle & $0-2 \mathrm{MC}$ & 1-2 MC, 0-5 PM & 1-2 PM & 5 PM & WD & Widely separated \\
\hline & Pelvic girdle & $\begin{array}{l}\text { PM } 1 \text { medial, } 2 \\
\quad \text { lateral }\end{array}$ & - & - & 3 PM & 2 PM (dorsal) & $\begin{array}{l}\text { Very close at the level of the } \\
\text { posterior end of the } \\
\text { ischium }\end{array}$ \\
\hline \multirow[t]{2}{*}{$38-40-41$} & Pectoral girdle & $1 \mathrm{MC}, 1-2 \mathrm{PM}$ & $3 \mathrm{MC}, 3-6 \mathrm{PM}$ & $1 \mathrm{PM}$ & 2-4 PM & WD & $\begin{array}{l}\text { Close to each other. } \\
\text { Ligamentous connective } \\
\text { tissue between procora- } \\
\text { coids }\end{array}$ \\
\hline & Pelvic girdle & WD & - & - & $3 \mathrm{PM} \mathrm{Pt}$ & 2-4 PM & $\begin{array}{l}\text { Synchondrotically in full } \\
\text { contact, or close at the } \\
\text { level of the ischium and } \\
\text { through connective tissue } \\
\text { to the level of the ilium } \\
\text { and pubis }\end{array}$ \\
\hline \multirow[t]{2}{*}{44} & Pectoral girdle & $2 \mathrm{PM}, 2-3 \mathrm{MM}$ & $5 \mathrm{PM}, 5 \mathrm{MM}$ & $1 \mathrm{PM}, 1-2 \mathrm{MM}$ & 1-4 MM & WD & $\begin{array}{l}\text { Nonoverlapped or slightly } \\
\text { overlapped at the level of } \\
\text { the procoracoids, and free } \\
\text { or connected by ligamen- } \\
\text { tous connective tissue }\end{array}$ \\
\hline & Pelvic girdle & $\begin{array}{l}1 \mathrm{MM} \text { (medial), } \\
2 \mathrm{MM} \text { (lateral) }\end{array}$ & - & - & $3 \mathrm{MM}, 1 \mathrm{Pt}$ & $2 \mathrm{MM}, 1 \mathrm{Pt}$ & $\begin{array}{l}\text { In full contact at the level of } \\
\text { the pubis. Synchondroti- } \\
\text { cally fused at the level of } \\
\text { the ischium, and by dense } \\
\text { connective tissue at the } \\
\text { level of the pubis. }\end{array}$ \\
\hline \multirow[t]{2}{*}{46} & Pectoral girdle & 2-4 MM & 5-6 MM, $1 \mathrm{Pt}$ & $1 \mathrm{MM}$ & 3- $5 \mathrm{MM}$ & WD & $\begin{array}{l}\text { Synchondrotically fused to- } \\
\text { gether at the anterior } \\
\text { cartilaginous procoracoids } \\
\text { extreme, or free and } \\
\text { without overlapping be- } \\
\text { tween each other. In the } \\
\text { most posterior region, the } \\
\text { procoracoids are slightly } \\
\text { overlapped and con- } \\
\text { nected through ligamen- } \\
\text { tous connective tissue }\end{array}$ \\
\hline & Pelvic girdle & WD & - & - & $2 \mathrm{MM}, 1 \mathrm{Pt}$ & $2 \mathrm{MM}$ & $\begin{array}{l}\text { Completely fused by carti- } \\
\text { lage or only in its fore and } \\
\text { aft ends, and through } \\
\text { connective tissue to the } \\
\text { pubis }\end{array}$ \\
\hline
\end{tabular}

Abbreviations: AEss = anterior region in both girdles, scapula-suprascapula end region, topologically equivalent to the anterior end of the ilium (AEi); AssS = anterior scapula-suprascapula surface equivalent to the anterior surface of ilium (ASi); $M C=$ mesenchymatic condensations; $M M=$ muscular mass; PM = premyogenic mass; $\mathrm{Pcp}=$ posterior in both girdles, posterior cocoracoid region topologically equivalent to the posterior acetabular (Pap); $\mathrm{Ppa}=$ posterior in both girdles, anterior procoracoidal equivalent to the anterior acetabular region (Paa); PsS = posterior scapula-suprascapula surface, equivalent to the posterior surface of ilium (PSi); $\mathrm{Pt}=$ pre-tendon; $\mathrm{WD}=$ without data

cartilaginous tissue and the acquisition of the adult morphology of the axial-girdle joints are synchronous. Ossification and formation of the axial-girdle joints in the pectoral girdle precede those of the pelvic girdle. Initial development of the ventromedial region and establishment of contact between girdle halves is not synchronous. Complete differentiation of the ventromedial region requires more time in the pelvic girdle than in the pectoral girdle (Figure 8).

Regarding the tissue development of girdles, a general pattern of advanced development of the tissues of the pelvic girdles emerges as both girdles are compared (Table 5). In the initial developmental stages
(36-37), the pelvic girdle has pre-muscular tissue in all its regions, whereas mesenchymal condensations remain in some areas of the pectoral girdle. In Stages 38-41, a pre-tendon develops in the pelvic girdle, whereas it first appears in Stage 46 in the pectoral girdle. At Stage 44 the pelvic girdle has mature muscles, whereas the pectoral girdle has pre-myogenic masses. There are fewer muscles in the pelvic girdle, and a total absence of muscle insertions on the anterior and posterior surfaces of the ilium (ASI and PSI, respectively) than in functionally equivalent areas of the pectoral girdle. These areas correspond to the anterior and posterior surfaces of the scapula-suprascapula (ASss and PSss, 
(a)

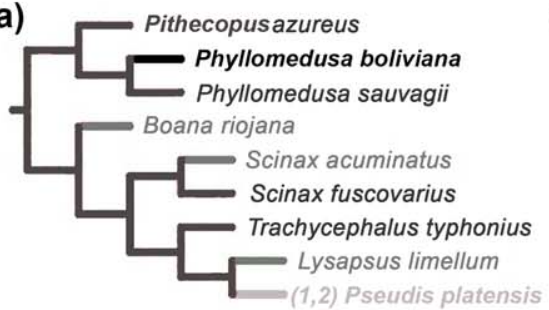

Dlarval II $\square$ larval III $\square$ larval IV $\square$ ambiguity (b)

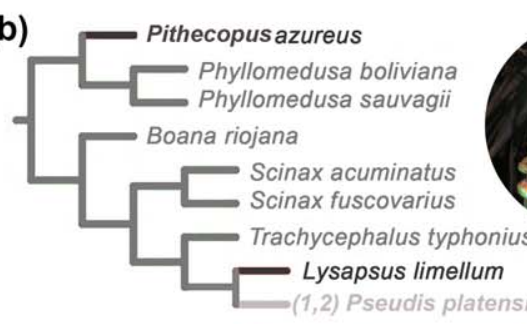

[ larval III Iarval IV a ambiguity

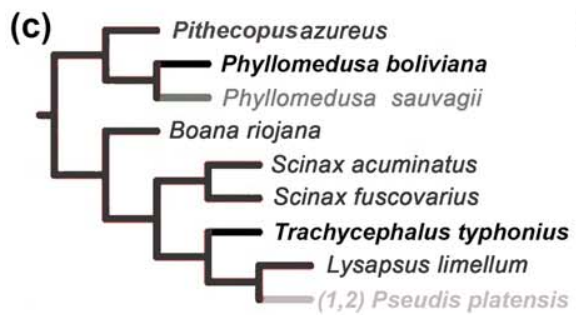

(d)

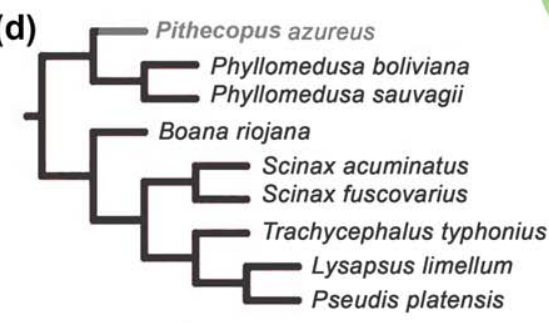

larval IV $\square$ early metamorphic

[larval III — larval IV Dearly metamorphic ambiguity

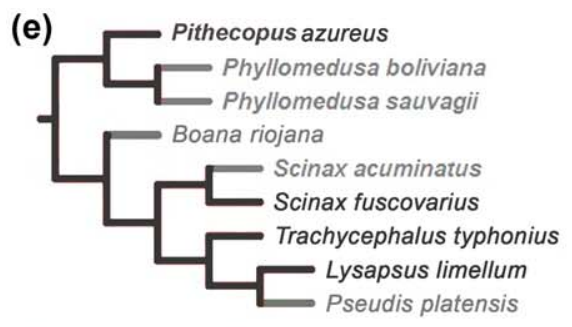

—early metamorphic $\square$ late metamorphic

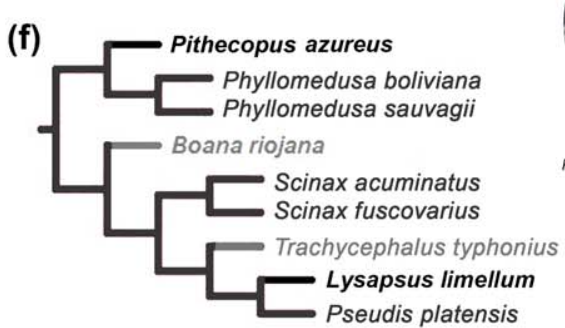

larval IV early metamorphic late metamorphic

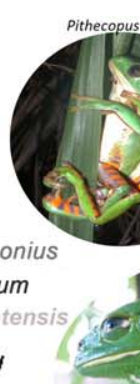

usureus 

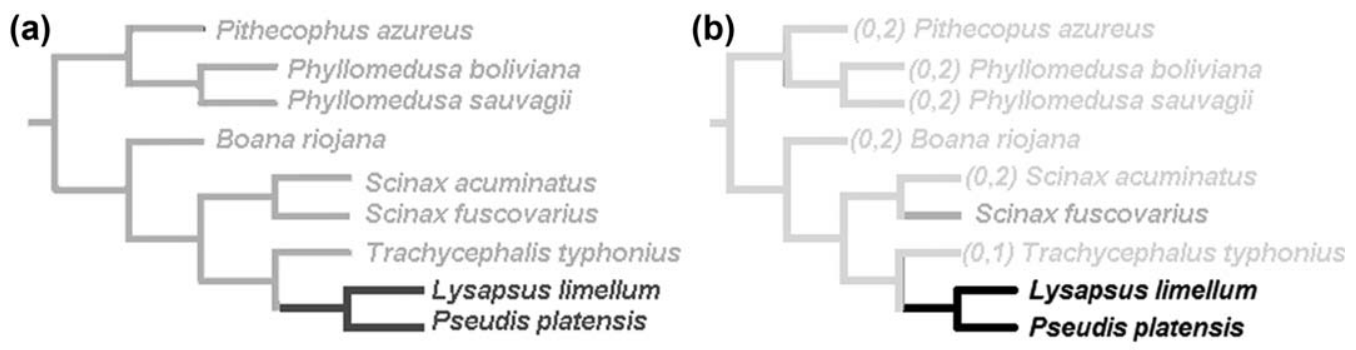

(c)

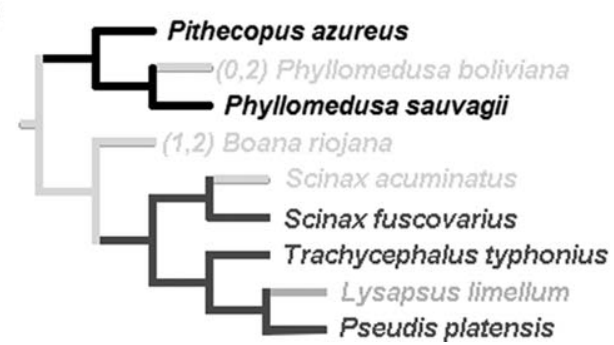

FIGURE 10 Ancestral state reconstruction on the phylogeny of Duellman et al. (2016) showing some characteristics of pseudids. (a) Character 9, beginning of contact between the pelvic girdle halves; (b) Character 16, number of cartilaginous elements of the girdles; (c) Character 17, number of visible sutures of the girdles. Characters 9 and 17: State $0=$ larval III (light gray); State $1=$ larval IV (dark gray); State 2 = early metamorphic (black). Character 16: Number of visible sutures of the girdles: (0) Five pectoral, none pelvic (light gray); (1) Four pectoral, none pelvic (dark gray); (2) Five pectoral, one pelvic (black)

number and topology of the muscles of the primaxial and abaxial domains; differentiation of timing of development of skeletal elements; number of mesenchymal condensations of the anatomical elements; degree of separation of halves of girdle; and nature of connection of girdle halves.

An important similarity in the development of pectoral and pelvic girdles is the strong relationship with the development of the proximal stylopodia of limbs. The development of the glenoid fossa and the acetabulum is intimately linked to the development of the epiphyses of the humerus and femur. This observation contradicts the hypothesis of Valasek et al. (2011; see also Diogo \& Ziermann, 2014), who proposed an "in-out" mechanism in which the development of the forelimb precedes that of the pectoral girdle, which suspends the proximal limb from the axial skeleton. Our data show that these elements develop together, as any ball and socket synovial joint; they arise from a single anlage which undergoes differentiation of an interzone followed by a cavitation process (Manzano et al., 2013; Nowlan \& Sharpe, 2014; Ponssa \& Abdala, 2016). These observations suggest that the similarities of the girdles may reflect the fact that they share the same type of joint. We postulate that there is a spatio-temporal developmental linkage between each girdle and it respective limb, particularly the stylopodium, owing to their formation of the same joint. This was previously stressed by Malashichev, Borkhvardt, Christ, and Scaal (2005), Pomikal and Streicher (2010), and Pomikal et al. (2011) in relation to the development of the pelvic girdle. These authors reported a developmental association between the limb and pelvic element in the avian pelvic girdle (at least between the limb field ectoderm and the pelvis formation, Malashichev et al., 2005), in Mus musculus (Pomikal \& Streicher 2010, pg. 123), and in Rana temporaria (Pomikal et al., 2011, pg. 288). The same developmental association characterizes the glenoid fossa and the humerus. Based on these findings we infer that girdles and proximal limb stylopodia constitute unique developmental modules that may have evolved together. Thus, the study of the transition from fins to limbs is incomplete without consideration of girdles. Through network analyses with anatomical elements of the pelvic girdle and hindlimbs in frogs, we found that the acetabulum and the hindlimb stylopodium belong to the same module (Dos Santos et al., 2017).

Most of the key events in the pelvic girdle-hindlimb development occur before most of those of the pectoral girdle forelimb complex (Figure 8). Two events occur early in the pectoral region namely, initial ossification processes and the differentiation of the abaxial domain region. Given that development of the pectoral girdle and the forelimbs in anurans occurs mostly within the branchial cavity, the structures are less affected by external stimuli than are the pelvic girdle and hindlimb. This possibly accounts for the delay in maturation of the pectoral girdle that we observed.

The optimization analysis shows that larval Stage III is the ancestral state for key developmental events in both girdles. Differences in the timing of appearance of some structures such as mesenchymal condensations or premyogenic masses, generate interesting heterochronic patterns, particularly in pseudids. These patterns are in accord with the many literature reports of frequent heterochronic changes in pseudids (de Sá \& Lavilla, 1997; Fabrezi \& Goldberg, 2009; Fabrezi, Quinzio, \& Goldberg, 2009, 2010). A general delay in the developmental processes which also characterize other aquatic species such as Telmatobius (Barrionuevo, 2013) and Xenopus laevis (Porro \& Richards, 2017), is thought to be related to spending more time in the water (Laurin, Girondot, \& Loth, 2004).

Our data indicate that despite heterochronic events being common in anurans, certain developmental events occur at interspecifically 
similar stages, thereby preventing any heterochronic shifts. The union of the halves of the pectoral girdles occurs at only one stage (Stage 41/ 42; Figure 8), whereas it can occur in several stages (e.g., Stages 3541; Figure 8) in the pelvic girdle. The halves of the pectoral girdle unite at the same time the forelimbs emerge from the branchial chamber, when the axial-girdle linkage is totally differentiated. These events also are coincident with the complete maturation of muscles, bones, and tendons (Manzano et al., 2013), supporting the existence of a phenocritical period for anurans (Ponssa \& Abdala, 2016). This period coincides with the assemblage of the locomotor elements such that the early metamorphic froglet can function in a terrestrial environment (Manzano et al., 2013). Our data show that the early metamorphic stage is the ancestral state, which reflects a correlate between the ontogeny and evolutionary history of the limbs and girdles.

Interspecific diversity in the developmental timing of the pectoral girdle is greater than that of the pelvic girdle, thereby implying more interspecific heterochrony. The many heterochronic events suggest that there are more possibilities to generate new morphologies in the pectoral girdle compared to the pelvic girdle.

The presence of dermal bones in the pectoral girdle supports the notion of its close relationship with the skull (Carroll \& Holmes, 2007; McGonell, 2001); thus, the posterior region of the skull and the dermal region of the pectoral girdle may represent parts of a joint. If so, both would originate from the same mesenchymal blastema, such as the proximal limb stylopodium and its corresponding girdle region do. Six muscles connect the pectoral girdle and the axial skeleton, from which two connect the skull with the vertebral column. One of them is the cucullaris, the iconic muscle related to the origin of the vertebrate neck (Abdala \& Diogo, 2010; Ericsson et al., 2013). In anurans, only one muscle, the levator scapulae superior, is attached to the single cervical vertebra (the atlas). Thus, this muscle is more closely associated with the neck than is the cucullaris, which is probably a head muscle (Nagashima et al., 2016). The levator scapulae receives motor supply from the cervical plexus (Frank, Wenk, Stern, Gottlieb, \& Moscatello, 1995).

The shapes of the pectoral girdle elements are more variable than those of the pelvic girdle. For example, the suprascapula has at least five different shapes, whereas the analog of the pelvic girdle, the anterior extreme of the ilium, has three configurations. The region of contact of the pectoral girdle halves is highly variable. The shape and development of the sternal zone varies, along with the zone of contact between the halves. For example, the anterior ends of the procoracoids can be synchondrotically fused, but the posterior end are separated by a ligamentous tissue (Kaplán, 2000), a tendinous-like highly organized tissue (this study). In contrast, in the pelvic girdle, a highly compact and disorganized tissue fills the space between the girdle halves; this tissue remains vestigial until metamorphosis. Researchers have mentioned that the mesenchymal cells condense in places where organs bend or form spaces between contact structures (Baleeva, 2001; Kovalenko, 1992) and that the growth of the scapular-suprascapular cartilage occurs primarily through the recruitment of adjacent mesenchymal cells. Thus, the uneven distribution of these cells around the girdle would determine their growth (Borkhvardt, 1991; Borkhvardt \& Baleeva, 2002). We found that during development, the halves of the pectoral girdle are separated from each other and connected by ligamentous connective tissue, whereas the halves of the pelvic girdle are close together and are almost completely connected synchondrotically. Given the wide space between the halves of the pectoral girdle, it is possible that more mesenchymal condensation might be generated. This might explain the greater number of elements in the pectoral girdle, including its only mobile joint. Shearman (2008) mentioned the importance of the differences in the organization of connective tissue and chondrocytes within the shaped joints of the pectoral girdle in the adult morphology. Baleeva (2001) found that the myomeres in some anurans are dorsally wider in the anterior part of the body, and abruptly narrow sharply toward the posterior end of the notochord. Borkhvardt and Baleeva (2002) reported that in Salamandrella keyserlingii, the body grows more intensely upward than downward during larval development in the region that we identified as the primaxial domain of the pectoral girdle. Taken together, these observations seem to suggest that morphogenetic activity in the anterior dorsal body region is considerably greater than in the posterior part. This may be related to historical evolutionary processes that first produced the pectoral girdle of tetrapods (Sears et al., 2015; Zhu et al., 2012).

There are five evident muscular connections in each of primaxial and abaxial domains of the pectoral girdle whereas the pelvic girdle has only two muscular connections in the primaxial domain and 18 in the abaxial domain. Clearly, there are remarkable differences in the muscular frameworks of the girdles, with the more variable zones located away from the sagittal body plane.

Our data complement the hypothesis formulated by Diogo et al. (2013) and elaborated by Diogo and Molnar (2014), Diogo and Tanaka (2014), Diogo and Ziermann (2014, 2015), Sears et al. (2015), and Diogo, Ziermann, Molnar, Siomava, and Abdala (2018). These authors compared the gross anatomy of the fore- and hindlimbs of representative taxa of all major groups of extant fish and tetrapods. They also reviewed developmental, morphological, and genetic data involving the pectoral and pelvic girdles of tetrapods. We add a comparative analysis of pectoral and pelvic skeletal structures, muscles, and other soft tissues (e.g., connective tissues, tendons, and ligaments), as well as developmental data. There are remarkable differences between the pectoral and pelvic girdles in anurans, and it is thought that anatomically, these girdles differed markedly from each other in the earliest fishes (Diogo et al., 2018). This parallelism may reflect similar biomechanical requirements of terrestrial locomotion-that is, the acquisition of ball- and -socket joints linking the stylopodial segments to their respective girdles to configure weight-bearing appendages. As such, this similarity is homoplastic and it should not be attributed to serial homology.

\section{ACKNOWLEDGMENTS}

The funding for this study comes from a CONICET PIP 389 and ANPCYT PICT 2016-2772 grants to VA, and ANPCyT PICT 20151618 to MLP. We are also grateful to Susana Mangione, Diego Baldo, Daniela Miotti, and Florencia Vera Candioti for their contribution to this paper. We thank the anonymous reviewers for their careful reading of our manuscript and their insightful comments and suggestions. 


\section{AUTHOR CONTRIBUTIONS}

Conceptualization: Virginia Abdala

Data curation: Mónica C. Soliz

Methodology: Virginia Abdala, María Laura Ponssa, Mónica C. Soliz

Investigation: Mónica C. Soliz, María Laura Ponssa, Virginia Abdala

Resources: Virginia Abdala, María Laura Ponssa

Writing-review-editing: Mónica C. Soliz, María Laura Ponssa, Virginia Abdala

Supervision: Virginia Abdala.

\section{ORCID}

Virginia Abdala (iD) http://orcid.org/0000-0002-4615-5011

María Laura Ponssa (D) http://orcid.org/0000-0002-8750-9680

\section{REFERENCES}

Abdala, V., \& Diogo, R. (2010). Comparative anatomy, homologies and evolution of the pectoral and forelimb musculature of tetrapods with special attention to extant limbed amphibians and reptiles. Journal of Anatomy, 217, 536-573.

Baleeva, N. (2001). Formation of the scapular part of the pectoral girdle in anuran larvae. Russian Journal of Herpetology, 8, 195-204.

Baleeva, N. (2009). Formation of the coracoid region of the anuran pectoral girdle. Russian Journal of Herpetology, 16, 41-50.

Barrionuevo, J. S. (2013). Osteology and postmetamorphic development of Telmatobius oxycephalus (Anura: Telmatobiidae) with an analysis of skeletal variation in the genus. Journal of Morphology, 274(1), 73-96.

Boisvert, C. A. (2005). The pelvic fin and girdle of Panderichthys and the origin of tetrapod locomotion. Nature, 438(7071), 1145-1147.

Borkhvardt, V. G. (1991). Regularities of the development of the cartilaginous elements in vertebrate ontogenesis. Zhurnal Obshchei Biologii, 52, 627-640.

Borkhvardt, V. G., \& Baleeva, N. V. (2002). Development of the pectoral girdle in larvae of Siberian salamander Salamandrella keyserlingii. (Amphibia, Hynobiidae). Russian Journal of Herpetology, 9, 177-184.

Boulenger, G. A. (1882). Catalogue of the Batrachia Salientia s. Ecaudata in the collection of the British Museum (2nd ed.). London, UK: Taylor and Francis.

Boulenger, G. A. (1902). Descriptions of new batrachians and reptiles from the Andes of Peru and Bolivia. Annals and Magazine of Natural History, 10, 394-402.

Carroll, R. L., \& Holmes, R. B. (2007). Evolution of the appendicular skeleton of amphibians. In B. K. Hall (Ed.), Fins into limbs: Evolution, development, and transformation (pp. 185-224). Chicago, IL: University of Chicago Press.

Coates, M. I., \& Ruta, M. (2007). Skeletal changes in the transition from fins to limbs. In B. K. Hall (Ed.), Fins into limbs: Evolution, development, and transformation (pp. 15-38).Chicago, IL: University of Chicago Press.

Cope, E. D. (1862). Catalogue of the reptiles obtained during the explorations of the Paraná, Paraguay, Bermejo and Uruguay Rivers by Captain Thomas L. Page, U. S. N. and those procured by Lt. N. Michler, U. S. Top. Eng. Commander of the expedition conducting the survey of the Atrato River. Proceedings of the National Academy of Sciences, Philadelphia, 14, 346-359. de Sá, R. O., \& Lavilla, E. O. (1997). The tadpole of Pseudis minuta (Anura: Pseudidae), an apparent case of heterochrony. Amphibia Reptilia, 18, 229-240.

Diogo, R., Linde-Medina, M., Abdala, V., \& Ashley-Ross, M. A. (2013). New, puzzling insights from comparative myological studies on the old and unsolved forelimb/hindlimb enigma. Biological Reviews of the Cambridge Philosophical Society, 88, 196-214.

Diogo, R., \& Molnar, J. (2014). Comparative anatomy, evolution, and homologies of tetrapod hindlimb muscles, comparison with forelimb muscles, and deconstruction of the forelimb-hindlimb serial homology hypothesis. Anatomical Record, 297, 1047-1075.

Diogo, R., \& Tanaka, E. M. (2014). Development of fore- and hindlimb muscles in GFP-transgenic axolotls, morphogenesis, the tetrapod bauplan, and new insights on the forelimb-hindlimb enigma. Journal Experimental Zoology, 322, 106-127.

Diogo, R., \& Ziermann, J. M. (2014). Development of fore- and hindlimb muscles in frogs, morphogenesis, homeotic transformations, digit reduction, and the forelimb-hindlimb enigma. Journal of Experimental Zoology, 322, 86-105.

Diogo, R., \& Ziermann, J. M. (2015). Muscles of chondrichthyan paired appendages, comparison with osteichthyans, deconstruction of the fore-hindlimb serial homology dogma, and new insights on the evolution of the vertebrate neck. Anatomical Record, 298, 513-530.

Diogo, R., Ziermann, J. M., Molnar, J., Siomava, N., \& Abdala, V. (2018). Muscles of chordates: Development, homologies and evolution. Oxford, UK: Taylor and Francis.

Dos Santos, D., Fratani, J., Ponssa, M. L., \& Abdala, V. (2017). Network architecture associated with the highly specialized hindlimb of frogs. PLoS One, 12(5), e0177819. https://doi.org/10.1371/journal.pone. 0177819

Dubois, A. (2017). The nomenclatural status of Hysaplesia, Hylaplesia, Dendrobates and related nomina (Amphibia, Anura), with general comments on zoological nomenclature and its governance, as well as on taxonomic databases and websites. Bionomina, 11(1), 1-48.

Duellman, W. E., Marion, A. B., \& Hedges, S. B. (2016). Phylogenetics, classification, and biogeography of the treefrogs. (Amphibia, Anura, Arboranae). Zootaxa, 4104, 1-109.

Duellman, W. E., \& Trueb, L. (1986). The biology of amphibians. Baltimore, MD: The Johns Hopkins University Press.

Emerson, S. (1979). The iliosacral articulation in frogs: Form and function. Biological Journal of the Linnean Society, 11, 153-168.

Ericsson, R., Knight, R., \& Johanson, Z. (2013). Evolution and development of the vertebrate neck. Journal of Anatomy, 222, 67-78. https://doi.org/10.1111/j.1469-7580.2012.01530.x

Fabrezi, M., \& Goldberg, F. J. (2009). Heterochrony during skeletal development of Pseudis platensis (Anura, Hylidae) and the early offset of skeleton development and growth. Journal of Morphology, 270, 205220.

Fabrezi, M., Quinzio, S., \& Goldberg, J. (2009). The giant tadpole and the delayed metamorphosis of Pseudis platensis Gallardo, 1961 (Anura, Hylidae). Journal of Herpetology, 43, 228-243.

Fabrezi, M., Quinzio, S., \& Goldberg, J. (2010). The ontogeny of Pseudis platensis (Anura, Hylidae): Heterochrony and the effects of larval development on the postmetamorphic life. Journal of Morphology, 271, 496-510.

Frank, D. K., Wenk, E., Stern, J. C., Gottlieb, R. D., \& Moscatello, A. L. (1995). A cadaveric study of the motor nerves to the levator scapulae muscle. Otolaryngology - Head and Neck Surgery, 117, 671-680.

Goloboff, P. A., Farris, J. S., \& Nixon, K. C. (2008). TNT, a free program for phylogenetic analysis. Cladistics, 24, 774-786. 
Gosner, K. L. (1960). A simplified table for staging anuran embryos and larvae with notes on identification. Herpetologica, 16, 183-190.

Kaplán, M. (2000). The pectoral girdles of Rana rugulosa (Ranidae) and Nesomantis thomasseti (Sooglossidae). Herpetologica, 56, 188-195.

Koslowsky, J. (1895). Batracios y Reptiles de Rioja y Catamarca (República Argentina), recogidos durante los meses de febrero á mayo de 1895 (Expedición del Director del Museo). Revista del Museo de La Plata, 6, 359-370.

Kovalenko, E. E. (1992). The anomalities of vertebrate column in anura, Izd. Sankt-Peterburg, Russia: SPbU.

Laurin, M., Girondot, M., \& Loth, M. M. (2004). The evolution of long bone microanatomy and lifestyle in lissamphibians. Paleobiology, 30, 589-613.

Lutz, A. (1925). Batraciens du Brésil. Comptes Rendus et Mémoires Hebdomadaires des Séances de la Société de Biologie et des ses Filiales. Paris, 93, 211-214.

Malashichev, Y., Borkhvardt, V., Christ, B., \& Scaal, M. (2005). Differential regulation of avian pelvic girdle development by the limb field ectoderm. Anatomy and Embryology, 210, 187-197.

Manzano, A. (1997). Estudio comparativo de la miología de la cintura pectoral de algunos Phyllomedusinos (Anura: Hylidae). Bollettino del Museo regionale di Scienze Naturali di Torino, 15, 255-277.

Manzano, A. S., \& Barg, M. (2005). The iliosacral articulation in Pseudinae (Anura, Hylidae). Herpetologica, 61, 259-267.

Manzano, A., Abdala, V., Ponssa, M. L., \& Soliz, M. (2013). Ontogeny and tissue differentiation of the pelvic girdle and hind limbs of anurans. Acta Zoologica, 94, 420-436.

McGonell, I. (2001). The evolution of the pectoral girdle. Journal of Anatomy, 199, 189-194.

Nagashima, H., Sugahara, F., Watanabe, K., Shibata, M., Chiba, A., \& Sato, N. (2016). Developmental origin of the clavicle, and its implications for the evolution of the neck and the paired appendages in vertebrates. Journal of Anatomy, 229(4), 536-548. https://doi.org/10. 1111/joa.12502

Nixon, K. C. (2002). WinClada ver. 1.00.08. Ithaca, NY: Author.

Nowlan, N. C., \& Sharpe, J. (2014). Joint shape morphogenesis precedes cavitation of the developing hip joint. Journal of Anatomy, 224, 48489.

Pomikal, C., Blumer, R., \& Streicher, J. (2011). Four-dimensional analysis of early pelvic girdle development in Rana temporaria. Journal of Morphology, 272(3), 287-301.

Pomikal, C., \& Streicher, J. (2010). 4D-analysis of early pelvic girdle development in the mouse (Mus musculus). Journal of Morphology, 271(1), 116-126.

Ponssa, M. L., \& Abdala, V. (2016). Phenotypical expression of reduced mobility during limb ontogeny in frogs, the knee-joint case. PeerJ, 4, e1730. https://doi.org/10.7717/peerj.1730

Ponssa, M. L., Goldberg, J., \& Abdala, V. (2010). Sesamoids in anurans, new data, old issues. Anatomical Record, 293(10), 1646-1668.
Porro, L. B., \& Richards, C. T. (2017). Digital dissection of the model organism Xenopus laevis using contrast-enhanced computed tomography. Journal of Anatomy, 231, 169-191.

Přikryl, T., Aerts, P., Havelková, P., Herrel, A., \& Rocek, Z. (2009). Pelvic and thigh musculature in frogs (Anura) and origin of anuran jumping locomotion. Journal of Anatomy, 214, 100-139.

Robovská-Havelková, P. (2010). How can ontogeny help us to understand the morphology of anuran pectoral girdle?. Zoomorphology, 129, 121-132.

Ročková, H., \& Roček, Z. (2005). Development of the pelvis and posterior part of the vertebral column in the Anura. Journal of Anatomy, 206, 17-35.

Sears, K. E., Capellini, T. D., \& Diogo, R. (2015). On the serial homology of the pectoral and pelvic girdles of tetrapods. Evolution, 69(10), 2543-2555.

Shearman, R. M. (2005). Growth of the pectoral girdle of the leopard frog, Rana pipiens (Anura: Ranidae). Journal of Morphology, 264(1), 94-104.

Shearman, R. M. (2008). Chondrogenesis and ossification of the lissamphibian pectoral girdle. Journal of Morphology, 269(4), 479-495.

Shubin, N. H., Daeschler, E. B., \& Jenkins, F. A. (2014). Pelvic girdle and fin of Tiktaalik roseae. Proceedings of the National Academy of Sciences of the United States of America, 111(3), 893-899.

Simons, V. (2008). Morphological correlates of locomotion in anurans, limb length, pelvic anatomy and contact structures (Master thesis). College of Arts and Sciences of Ohio University, Athens, $\mathrm{OH}$.

Trueb, L. (1973). Bones, frogs and evolution. In J. L. Vial (Ed.), Evolutionary biology of the anurans: Contemporary research on major problems (pp. 65-132). Columbia: The University Missouri Press.

Valasek, P., Theis, S., DeLaurier, A., Hinitsf, Y., Lukea, G. N., Ottoa, A. M., . . Patel, K. (2011). Cellular and molecular investigations into the development of the pectoral girdle. Developmental Biology, 357, 108-116.

Wassersug, R. J. (1976). A procedure for differential staining of cartilage and bone in whole formalin-fixed vertebrates. Stain Technology, 51, 131-134.

Zhu, M., Yu, X., Choo, B., Wang, J., \& Jia, L. (2012). An antiarch placoderm shows that pelvic girdles arose at the root of jawed vertebrates. Biology Letters, 8, 453-456.

\section{SUPPORTING INFORMATION}

Additional Supporting Information may be found online in the supporting information tab for this article.

How to cite this article: Soliz MC, Ponssa ML, Abdala V. Comparative anatomy and development of pectoral and pelvic girdles in hylid anurans. Journal of Morphology. 2018;00:1-21. https://doi.org/10.1002/jmor.20820 